\title{
REJOINDER
}

\section{TREATIES AND PUBLIC LAWMAKING: A TEXTUAL AND STRUGTURAL DEFENSE OF NON-SELF-EXECUTION}

\author{
By John C. Yoo*
}

This Rejoinder responds to Professors Flaherty and Vázquez by advancing textual and structural constitutional arguments in defense of the doctrine of non-self-executing treaties. It first responds by raising several historical and contextual problems with Professor Flaherty's Response. It then argues that requiring congressional implementation of treaties that regulate matters within Congress's Article I, Section 8 powers respects the Constitution's basic separation of the legislative and executive powers. This approach also ensures that treaties, which are asserted to be free from the Constitution's federalism and the separation of powers limitations, will not assume an unbounded legislative power, and it promotes the Constitution's principle that domestic legislation be made by demoeratic processes. Professor Yoo criticizes the position that the Supremacy Clause's text requires automatic judicial enforcement of treaties as too simple and inconsistent with practice both in the treaty area and in the enforcement of federal statutory and constitutional provisions.

\section{INTRODUCTION}

Although both Professors Flaherty and Vázquez make excellent arguments on behalf of self-executing treaties, they fail to convince. In this Rejoinder, I will explain why. Though Professor Flaherty is not convinced by "Globalism and the Constitution," I read him as admitting that the original understanding concerning the presence of treaties in domestic law is no longer settled. I I hope to explain in the first part of this Rejoinder why, despite his claims, the Founding materials continue to support my view. ${ }^{2}$ If the original understanding, however, is no longer conclusive, then other arguments become more probative. I understand

* Professor of Law, University of California at Berkeley School of Law (Boalt Hall).

1. See Martin S. Flaherty, History Right?: Historical Scholarship, Original Understanding, and Treaties as "Supreme Law of the Land," 99 Colum. L. Rev. 2095 (1999) [hereinafter Flaherty, History Right].

2. I read Flaherty as also agreeing with me that examining the original understanding is an important, if not the preferred, method for determining the constitutional allocation of powers in foreign affairs. This is a methodology I have pursued on other foreign affairs questions. See, e.g., John C. Yoo, Clio at War: The Misuse of History in the War Powers Debate, 70 U. Colo. L. Rev. 1169, 1172-75 (1999) [hereinafter Yoo, Clio]; John C. Yoo, The New Sovereignty and the Old Constitution: The Chemical Weapons Convention and the Appointments Clause, 15 Const. Commentary 87, 105-11 (1998) [hereinafter Yoo, New Sovereignty]; John C. Yoo, The Contimuation of Politics by Other Means: The Original Understanding of War Powers, 84 Cal. L. Rev. 167 256-65 (1996) [hereinafter Yoo, War Powers]. 
Professor Vázquez to argue that textual and structural arguments present the best methods for resolving the question of self-executing treaties. ${ }^{3}$ As "Globalism" did not address such issues, this Rejoinder will advance textual and structural arguments in defense of a doctrine of non-self-executing treaties, particularly in areas within Congress's Article I powers. ${ }^{4}$ No scholar has yet made a serious effort to explain how the Constitution's text and structure support a rule of treaty non-self-execution.

Further examination of these factors shows that, far from "run[ning] counter to the language, and spirit, and history ... of the Constitution," 5 non-self-execution represents the best method for reconciling treatymaking with the processes of public lawmaking that are imposed by the text and structure of the Constitution. Efforts to render all treaties self-executing create serious difficulties in the public lawmaking system, because treaties do not undergo the same process that applies to other forms of federal law, nor are they subject to the same constitutional limitations that apply to statutes. Further, as "Globalism" discussed, ${ }^{6}$ the growing internationalization of life is blurring the lines between foreigu and domestic affairs. Non-self-execution offers a way to avoid the structural difficulties wrought by globalization and the attendant disruption of the lawmaking process. In order to maintain separation between treatymaking and lawmaking, international agreements that undergo the treaty process set out in Article II, Section 2 should not generally be judicially enforceable unless Congress passes implementing legislation. Action by any one of the three branches of government can ensure this result: The President can refuse to negotiate self-executing treaties on belialf of the United States, the Senate can attach reservations to all treaties that render them non-self-executing, and the courts can refuse to enforce treaty provisions that lack a clear statement of self-execution or that have not received implementation by statute. Unlike the positions taken by Professors Flaherty and Vázquez, this Rejoinder does not condemn the conduct of the three branches of government, but rather seeks to explain how the constitutional text and structure support current practice.

Critics of non-self-execution-of whom Vázquez is a leading exponent-make the simplistic argument that the text of the Supremacy Clause compels courts to enforce treaties without further implementation

3. See Carlos Vázquez, Laughing at Treaties, 99 Colum. L. Rev. 2154 (1999) [hereinafter Vázquez, Laughing at Treaties]. This was not, however, an argument that he made in his earlier work on treaties, which relied to a great extent on the original understanding of the Constitution for support. See, e.g., Carlos Vázquez, Treaty-Based Rights and Remedies of Individuals, 92 Colum. L. Rev. 1082, 1097-1110 (1992) [hereinafter Vázquez, Treaty-Based Rights] (arguing that the Framers understood treaties to be operative on states, not on individuals).

4. John C. Yoo, Globalism and the Constitution: Treaties, Non-Self-Execution, and the Original Understanding, 99 Colum. L. Rev. 1955 (1999) [hereinafter Yoo, Globalism].

5. Louis Henkin, Foreign Affairs and the Constitution 201 (2d ed. 1996).

6. See Yoo, Globalism, supra note 4, at 6 . 
by the political branches. ${ }^{7}$ The text of the Supremacy Clause, however, only declares that treaties, like the Constitution and federal statutes, are superior to state law. Article VI does not address how they are to be made supreme, nor does it require that the Constitution, treaties, and federal statutes always be justiciable in court. Instead, the Supremacy Clause simply makes clear the superiority of federal law to state law, without specifying how the branches of government are to make and implement that law. This Rejoinder will argue that other textual and structural elements allow the three branches to defer execution of a treaty until the President and Congress can determine how best to implement the nation's treaty obligations. Approaching treaties in this manner maintains a clear distinction between the power to make treaties and the power to legislate, between executive and congressional power, and between international and domestic law.

This Rejoinder's examination of the text and structure of the Constitution responds to Flaherty and Vázquez with two possible doctrinal rules. ${ }^{8}$ The first, a "hard" rule, directly implements the best reading of the Constitution: Treaties cannot receive judicial enforcement in areas that fall within Congress's Article I, Section 8 powers, without statutory implementation by Congress. To do otherwise would allow an executive power-treatymaking - to trump Article I's vesting of the legislative power solely in Congress. If a treaty, however, regulates a matter that falls within the province of the states, it may be self-executing because by definition it does not conflict with Congress's legislative powers. Under the "soft" rule, courts can remain true to the text, structure, and original understanding of the Constitution by requiring the treatymakers to issue a clear statement if they want a treaty to be self-executing. Judicial adoption of a clear statement rule favoring non-self-execution protects public lawmaking values of constitutional dimensions. ${ }^{9}$ Such an approach ensures that the treaty power reflects the democratic principles that generally govern the process of public lawmaking. Presidential participation in treatymaking and non-self-execution together see to it that the treaty power remains true to the Constitution's majoritarian roots. Non-self-execution grants the political branches the discretion to decide how the nation will meet its international obligations and keeps the courts out of foreign policy matters for which they are ill-suited. Finally, non-self-exe-

7. See, e.g., Henkin, supra note 5, at 198-201; Jordan J. Paust, Self-Executing Treaties, $82 \mathrm{Am}$. J. Int'l L. 760, 760 (1988) (arguing that the distinction between self-executing and non-self-executing treaties is inconsistent with the Supremacy Clause); Vázquez, TreatyBased Rights, supra note 3, at 1104-1106 (arguing that the Supremacy Clause grants courts the power and duty to enforce and imterpret treaties); Vázquez, Laughing at Treaties, supra note 3 , at 2157 .

8. See infra text accompanying notes 138-144.

9. Cf. William N. Eskridge Jr. \& Philip P. Frickey, Quasi-Constitutional Law: Clear Statement Rules as Constitutional Lawmaking, 45 Vand. L. Rev. 593, 597 (1992) (arguing clear statement rules allow the Court to focus legislative attention on constitutional values). 
cution ensures that the national government's power to legislate will not become unlimited, even in an era of rapid globalization.

\section{HISTORY}

Professor Flaherty has made it his business to police the originalist arguments of constitutional law scholars of all stripes, but particularly those he believes to be "conservative," or, in the foreign relations law area, "isolationist." 10 In "History 'Lite' in Modern American Constitutionalism,"11 published in these pages, Flaherty criticized scholars for misusing history in making claims about constitutional meanings. In the course of setting out standards for the use of history, and in providing an excellent historiography of the framing, Flaherty concluded that much originalist scholarship falls "below standards of undergraduate history writing." 12 In a subsequent article, ${ }^{13}$ he extended this criticism to originalist defenders of the unitary presidency. ${ }^{14}$ Lately, he has criticized those who seek to place federalism limits on the treaty power ${ }^{15}$ by arguing that nothing in the founding record conclusively indicates that such limits were understood to exist. ${ }^{16}$

All of this is well and good. Flaherty and I agree that legal appeals to the Framers should obey minimum historical standards. We also agree on how this ought to be done-not just by resorting to the primary sources, contained mostly in the Documentary History of the Ratification of the Constitution, but also by using the wealth of secondary works about the Framing Period. While Flaherty has argued that much originahist scholarship fails to pay proper attention to both sets of sources, he seems to credit "Globalisin" with meeting his high methodological standards. We

10. See Martin S. Flaherty, Are We to be a Nation? Federal Power vs. "States' Rights" in Foreign Affairs, 70 U. Colo. L. Rev. 1277, 1309-11 (1999).

11. See Martin S. Flaherty, History "Lite" in Modern American Constitutionalism, 95 Colum. L. Rev. 523, 525-26 (1995) [hereinafter Flaherty, History Lite].

12. See id. at 526 .

13. See Martin S. Flaherty, The Most Dangerous Branch, 105 Yale L.J. 1725, 1750-51 (1996) [hereinafter Flaherty, Most Dangerous].

14. Particularly the views expressed in Steven G. Calabresi \& Saikrishna B. Prakash, The President's Power to Execute the Laws, 104 Yale L.J. 541, 549-50 (1994) (arguing that "the originalist textual and historical arguments for the unitary Executive, taken together, firmly establish the theory" of the unitary Executive); Steven G. Calabresi \& Kevin H. Rhodes, The Structural Constitution: Unitary Executive, Plural Judiciary, 105 Harv. L. Rev. 1153, 1215-16 (1992) (asserting that theories of broad congressional power to restrict federal court jurisdiction suggest limited congressional power to restructure the executive department); Saikrishna B. Prakash, Note, Hail to the Chief Administrator: The Framers and the President's Administrative Powers, 102 Yale L.J. 991, 991 (1993) (noting that "the Framers attempted to establish an executive who alone is accountable for executing federal law").

15. See, e.g., Curtis A. Bradley, The Treaty Power and American Federalism, 97 Mich. L. Rev. 390, 394 (1998) (arguing that federalism limits should be placed on the "plenary" treaty power) [hereinafter Bradley, "Treaty Power"].

16. See Flaherty, supra note 10, at 1311. 
also agree on what elements of the Framing are most important: the context established by British constitutional and political practice, the Critical Period, and the state ratification debates. Although he does not admit it, Flaherty must agree with my criticism of much of the foreign relations scholarship on treaties. While broad and certain in their declarations that the Framers intended treaties to be self-executing, previous works failed to undertake a careful review of the Constitution's ratification, not to mention the broader context set by the British and early national experiences. In sum, Flaherty does not dispute "Globalism's" larger points about the use of history by internationahists, nor "Globalism's" general approach to the Framing. 17

Where Flaherty and I disagree, however, is how best to read the most relevant evidence. Aside from plunging into the original sources themselves, third parties may find it difficult to evaluate the competing interpretations drawn by Flaherty and by "Globalism," since the correct reading of each speech or document depends on the reader's personal evaluation of the passages examined in context. However, this Rejomder can address the contextual arguments that Flaherty makes to spin the

17. See Flaherty, History Right, supra note 11, at 2099-105. Flaherty also must join me in rejecting Professor Vázquez's approach to originalism. Professor Vázquez argues that the ratification debates are relevant only insofar as they show that the states adopted the Constitution. Instead of exploring the ratification debates, Vázquez believes that the evidence from the Constitutional Convention, and a few other sources, such as the Federalist Papers, are the most relevant. See Vázquez, Laughing at Treaties, supra note 3, at 2162-63. This flies in the face of the conclusions reached by leading constitutional historians, who conclude that the ratification debates are the most important source for constitutional interpretation based on the Framing. See, e.g., Jack N. Rakove, Original Meanings: Politics and Ideas in the Making of the Constitution 94-130 (1996) (analyzing the developinent and importance of the idea of ratification in the Framing Period); Leonard W. Levy, Original Intent and the Framers' Constitution 17-29 (1988) (analyzing Madison's endorsement of the intent of the ratifiers as a valid means of determining constitutional meaning); Charles A. Lofgren, The Original Understanding of Original Intent?, 5 Const. Commentary 77, 111-13 (1988) (evidence from the framing period itself deinonstrates that while the Framers would have condemned the use of the Philadelphia Convention debates, they would have supported the use of evidence from the ratification). No one would have opposed Vázquez's view as much as James Madison. During the Jay Treaty debates, Madison rejected claims that the Philadelphia Convention's understandings should govern interpretation of the Treaty Clause. See James Madison, Speech on Jay Treaty, Apr. 6, 1796, in 16 The Papers of James Madison 290, 295-96 J.C.A. Stagg et al. eds., 1989) [hereinafter "Madison Papers"] (noting that the Convention "could never be regarded as the oracular guide in the expounding of the Constitution"). Vázquez's arguments create a serious flaw in internationalists' efforts to rely upon the original understanding to justify their reading of the Supremacy Clause's text. Indeed, inany of Vázquez's arguments about the use of history seem to counsel against using the original understanding at all in constitutional interpretation. While this may be a defensible interpretive stance, it is not the one taken by internationalists, who have long invoked the Framers to justify their criticisms of the actions of the political branches in both the treaty and war power areas. See Yoo, Globalism, supra note 4, at 1959-60; see also Yoo, Clio, supra note 2, at 1170-71 (discussing critiques of foreign affairs leveled by "nationalist" critics). 
sources his way. The context within which the Framers understood their actions is crucial; the manner in which a historian contextualizes these sources determines to a large extent the understandings that surface. Flaherty, for example, reads British and early American history as establishing a widely held understanding that all treaties were self-executing. Having reached this conclusion, Flalierty establishes a presumption that dismisses any contrary evidence for not clearly declaring an opposite intention. "Globalism," by contrast, treats the evidence as establishing a background rule that legislation was to address matters of domestic regulation. It understands the ratification discussions as a far more complex event, one which accommodated concerns about the relationship between treatymaking and lawmaking with a principle of non-self-execution in areas of congressional competence.

As an initial matter, however, I wish to clarify the claims made by "Globalism," because Flaherty has read its conclusions too broadly. "Globalism" does not contend that the treaty power would have originally been understood as failing to bind the nation, the states, and the people to international agreements. Nor does "Globalism" argue that the Framers believed the House to have a formal role in treatymaking itself, or that every treaty required some sort of legislative confirmation. Rather, "Globalism" argues that the Framers saw a tension between the Supremacy Clause's efforts to make treaties binding on the nation, which the Articles of Confederation had failed to do, and Article I's vesting of all federal legislative power in Congress. This tension was resolved by explicit analogy to the British model, which allocated legislative authority to Parliament and treatymaking power to the executive. Since treaties continued to be executive in nature, as under the British Constitution, they could not exercise the legislative authority granted to Congress. When treaties encroached on areas within Congressional authority, "Globalism" argues, the Framers believed that the House would have a role, not by formally consenting to the treaty, but through its powers over legislation and budget in implementing the treaty. These powers gave the House an informal yet indispensable role in treatymaking, because by withholding implementation, the House could block a treaty's domestic effect. Consistent with Anglo-American understandings of the treaty and legislative powers, this approach accommodated the need for national unity in foreign affairs with the effort to give the national legislative power a firmer representative basis.

"Globalism," therefore, does not claim that all treaties must be nonself-executing. In particular, it does not address treaties that regulate areas outside of Congress's legislative powers. In such situations, the treaty power does not conflict with the vesting of the legislative power in Congress. Instead, the treaty power raises only federalism problems of the sort addressed by Missouri v. Holland, in which the Supreme Court denied 
that the Tenth Amendment limited the treaty power's scope. ${ }^{18}$ One could conclude that the best way to reconcile the Framers' decision to include the Supremacy Clause in its present form with Article I, and with their concerns about the relationship between the legislative and treaty powers, is to consider treaties as non-self-executing in areas within Congress's legislative powers, but as possibly self-executing in areas reserved to the states. In fact, reading Article II, Section 2; Article I, Section 8; and the Supremacy Clause in this manner presents a way of harmonizing some of Flaherty's points with the larger themes identified in "Globalism." I will examine the textual and structural implications of this reading of the treaty power in the following sections. Let it suffice for present purposes that many of Flaherty's conclusions and his interpretive moves show that treaties were understood to be supreme over contrary state law. "Globalism" does not dispute this conclusion, but addresses the different question of the relationslip between treaties and the federal legislative power. Flaherty's reading of the history does not truly come to grips with "Globalism's" arguments because he focuses on a different question.

Flaherty's critique also misses the mark in its discussion of what he calls the "substantive side" of historical method.19 While praising "Globalism" for its "procedural" use of the primary and secondary sources, he concludes that its story runs counter to the "basic thrust of the prevailing historical narrative." ${ }^{20}$ According to Flaherty, the Framers' treatment of the treaty power should parallel broader developments in their constitutional thinking. As described primarily by Gordon Wood, constitutional thought evolved from the initial revolutionary belief that Americans were defending their rights under the British Constitution, to the failed state experiments in unrestrained democracy during the Critical Period, to the Thermidorean reaction against pure democracy that characterized the Constitution. ${ }^{21}$ This is an important contextual point, because it would be surprising if the Framers had simgled out the treaty power for different treatment or, as Flaherty's colleague William Treanor has put it, "[f]or [the Framers] to believe that such a decision was appropriate, there would have had to have been some concern causing them to turn against the great tide of constitutional history."22

18. 252 U.S. 416,432 (1920).

19. Flaherty, History Right, supra note 1, at 2102.

20. Id.

21. See generally Gordon S. Wood, The Creation of the American Republic, 1776-1787 (1969).

22. William Michael Treanor, Fame, The Founding, and the Power to Declare War, 82 Cornell L. Rev. 695, 721 (1997). In responding to my earlier article on war powers, which parallels "Globalism" in several respects, Professor Treanor conceded that my description of war powers is consonant with at least some parts of early American constitutional thought. See id. at 720. Nonetheless, Treanor took me to task because he believed, in the case of war powers and perhaps of foreign affairs generally, that the Framers did intend to act in a "countercyclical" manner. See id. at 721, 756-59. There is just no pleasing the Fordham school of constitutional historians. 
The problem with this meta-criticism is that it is unclear whether developments regarding the allocation of the foreign affairs power followed the same pattern as domestic issues. As Flaherty himself acknowledges, ${ }^{23}$ historical work of the sort practiced by Bailyn, Wood, McDonald or Rakove have focused primarily on domestic constitutional issues. ${ }^{24}$ Notable exceptions ${ }^{25}$ do not fit within the broader framework developed by these historians. It could very well be the case that the foreign relations power, which remained at the national level throughout the Revolutionary, Critical and Framing Periods, was immune from the tumultuous developments that occurred in the constitutional thought of the period. That has been my argument in regard to the war powers ${ }^{26}$ and the conclusion of some historians in regard to other aspects of the executive power. 27

To the extent that we have a story of constitutional development, it remains unclear how to apply it to the treaty power. How, exactly, does Wood's thesis of a conservative reaction against unrestrained democracy during the Constitutional Convention explain the changes made to the allocation of the treaty power? On the one hand, the Philadelphia Con-

23. See Flaherty, History Right, supra note 1, at $\mathbf{2 1 1 5 .}$

24. In this respect, both Flaherty and Vázquez are mistaken in their attempts to make so much of a passing comment by Professor Rakove concerning the purpose of the Supremacy Clause:

Whatever uncertainty might bave persisted about the precise allocation of the authority to make treaties, the Framers were virtually of one mind when it came to giving treaties the status of law. ... the supremacy clause ... gave treaties the status of law and made them judicial enforceable through the Federal courts.

Jack N. Rakove, Solving a Constitutional Puzzle: The Treatymaking Clause as a Case Study, 1 Persp. Am. Hist. 233, 264 (1984). Both Professors Flaherty and Vázquez seize upon this statement as some sort of smoking gun, but they neglect to inform the reader that Professor Rakove's article was not about the Supremacy Clause or the relationship between the treaty and legislative powers, but about the division of the treaty power between the President and Senate. See Flaherty, History Right, supra note 1, at 2120; Vázquez, Laughing at Treaties, supra note 3, at 2162-63. While I have the greatest respect for Professor Rakove's work as a historian, I think that it goes too far to quote and rely upon Professor Rakove as if he were a Framer on a par with Madison.

25. See, e.g., Edward S. Corwin, National Supremacy: Treaty Power vs. State Power 296 (1913) (arguing that "the treaty-power of the United States is not constitutionally restricted by the police powers of the States"); Felix Gilbert, To the Farewell Address: Ideas of Early American Foreign Policy 71-75 (1961) (arguing that early American foreign policy was partially isolationist and partly internationalist); Frederick W. Marks III, Independence on Trial: Foreign Affairs and the Making of the Constitution 47, 90-95 (1973) (assaying the impact of trade and national defense considerations on the constitutional debates).

26. See Yoo, War Powers, supra note 2, at 218-41.

27. See, e.g., Willi Paul Adams, The First American Constitutions: Republican Ideology and the Making of the State Constitutions in the Revolutionary Era 271-75 (Rita \& Robert Kimber trans., 1980) (arguing that the executive power within states remained strong during this period); Charles C. Thach, Jr., The Creation of the Presidency 1775-1789: A Study in Constitutional History 34-54 (1923) (identifying a trend toward broader executive power among state constitutions adopted later in the Critical Period). 
vention delegates sought to increase rather than decrease the democratic checks on the treaty power-hence the late inclusion of the President in the process and Wilson's and Madison's failed efforts to give the House a formal role. ${ }^{28}$ This appears to run counter to the general theme that the Constitution sought to restrain democracy. On the other hand, the story of the treaty power, at a higher level of generality, runs in tandem with the Wood thesis of constitutional development: The treaty power initially rested solely in the Crown, with Parliament balancing the power with its authority over legislation; under the Articles, this executive power was diluted by a multi-nember executive (the Continental Congress) and by the states' unrestrained democracy; the Framers reacted by centralizing the treaty power and by placing the authority to implement treaties at the national level. Similarly, in the area of war powers, the Framers maintained the power to initiate hostilities in the executive, but gave Congress checking abilities through legislation and budgetary control. ${ }^{29}$ In foreign relations, then, the story of constitutional development played out by unifying executive powers in a national Presidency (or, in the case of the treaty power, in the President and Senate) and by creating a national legislature that balanced executive authority through its traditional powers over legislation and funding. By freeing the executive treatymaking authority from any legislative check, internationalists are the ones who are interpreting history at odds with the general outlines of constitutional development during the Framing. ${ }^{30}$

Flaherty's broader thesis runs into even more problems when compared against Framing-era developments in constitutional thought. After reading his Response, one would conclude that self-execution had long been the norm in the Anglo-American world. According to Flaherty, not only did the Framers of the federal Constitution generally understand that all treaties were self-executing law, but so too did Americans who lived under the Articles of Confederation and the British constitution. In response to "Globalism," Flaherty reconstructs a past in which treaties were forever self-executing. Not only should such historical unanimity give one pause, but it directly contradicts the beliefs of numerous Framers, ${ }^{31}$ of other internationalists, ${ }^{32}$ and of British legal histori-

28. See Yoo, Globalism, supra note 4, at 1967-68.

29. See Yoo, War Powers, supra note 2, at 241-86.

30. Indeed, Professor Treanor acknowledges that this story of the foreign relations power has parallels with the Wood thesis of constitutional development. However, Treanor claims that in later state constitutions, governors were awarded significantly less power than in the first versions. See Treanor, supra note 22, at 722.

31. See, e.g., Yoo, Globalism, supra note 4, at 2036, 2050-51, 2055-59, 2067-72 (citing Framers).

32. See, e.g., Carlos M. Vâzquez, The Four Doctrines of Self-Executing Treaties, 89 Am. J. Int'l L. 695, 698-99 \& n.20 (1995) (arguing that the Framers inserted the Supremacy Clause to deal with difficulties of non-self-executing treaties under the Articles of Confederation); Vâzquez, Laughing at Treaties, supra note 3, at 2158 n.14 (concluding 
ans, ${ }^{33}$ all of whom agree that the British treaty system was one of non-selfexecution. This proposition is so uncontroversial that in 1908 English legal historian Frederick Maitland could observe, "[s] uppose the queen contracts with France that English iron or coal shall not be exported to France-until a statute has been passed forbidding exportation, one may export and laugh at the treaty." 34 Indeed, even today the British system still requires an Act of Parliament before a treaty can become part of English law, enforceable in court. ${ }^{35}$ In a time of dramatic political and legal upheaval, Flaherty's account is just too neat. Where "Globahism" depicts substantial disagreement about the relationship between the treaty and legislative powers, beginning with the battles between Crown and Parliament, continuing through the Critical Period, and concluding with the ratification struggle, Flaherty believes that the self-executing nature of treaties, and their ability to trump the legislative power, was uncontroversial.

Not only does Flaherty smooth over too many bumps in the road, but he explains far too much. If self-executing treaties were as obvious as Flaherty believes, then there would have been no occasion for Parliament to have fought with the Crown, the Continental Congress should have encountered no problems in enforcing the Treaty of Paris, the Supremacy Clause would have amounted to declaratory surplusage, the debates of various framers about the legislative and funding roles of the House in treatymaking were unnecessary, and the Jay Treaty should have moved through Congress in a snap. If Flaherty were correct, a chorus of voices should have appeared, at different critical moments, to explain that the courts would play the primary role in treaty enforcement. Where "Globalism" seeks to explain the different, and at times contradictory, thoughts of the Framing generation on treaties and legislation, Flaherty too quickly seeks unanimity and simplicity in his interpretation. History does not yield so readily to the Law of Ockham's Razor.

Indeed, Flaherty's conclusions appear even more dubious when compared to the standards set by one of my favorite legal writers on constitutional history, Flaherty himself. In previous articles, Flaherty has criticized what he calls the "narrow originahist approach" for seeking rules of decision that are too precise from a history that all too often displays tensions, contradictions and ambiguity. ${ }^{36}$ In particular, he sharply attacked Professors Steven Calabresi's and Saikrishna Prakash's originalist

that British practice toward treaties was one of non-self-execution, and that Framers so understood it).

33. See, e.g., 10 Sir William Holdsworth, A History of English Law 373-74 (1938) (“[T] he King has the sole power of making treaties."); 11 id. at 253, 268 ("[T] he Crown, by an exercise of its treaty making power, cannot affect the legal rights of its subjects, because the law cannot be changed by the prerogative.").

34. Frederick W. Maitland, The Constitutional History of England 425 (1908); see also id. at 424-25.

35. See Ian Brownhe, Principles of Public International Law 47-48 (4th ed. 1990).

36. Flaherty, Most Dangerous, supra note 13, at 1812. 
defense of the unitary executive ${ }^{37}$ because their use of history, rather than making sense of complexity, sought to reduce it into a simple rule. ${ }^{38}$ According to Flaherty, Calabresi and Prakash should have inferred the general themes that governed the Framers' thoughts on the separation of powers and then "translated" or "synthesized" them to the changed circumstances of today, all in a manner that maintained "fidelity" to the Framers' understanding. ${ }^{39}$ In regard to the separation of powers, Flaherty concluded, the Framers sought to promote checks and balances, democratic accountability, and energy in the executive, rather than choosing one over the other as required by the unitary executive thesis. ${ }^{40}$ Given the astounding growth of presidential power in the last two hundred years, Flaherty argued, fidelity to the Framers justifies legislative checks such as independent administrative agencies, independent counsels, legislative vetoes and restrictions on the removal power. ${ }^{41}$

"History Right," oddly enough, puts me in the catbird seat usually reserved for Flaherty, and Flaherty in the woeful place last held by Calabresi and Prakash. It seems that on the question of self-executing treaties, Flaherty is the one who has defined his inquiry and his rule too narrowly for the history to bear. He has taken some comments that the Framers made concerning the supremacy of treaties in regard to state law, essentially a federalism issue, and sought to convert them into a onesize-fits-all rule that solves broader separation of powers problems as well. Instead of highlighting and explaining tensions in the Framers' thought, he seeks to marshal them all in a common direction toward the ultimate end of self-executing treaties. In contrast, "Globalism" identified general themes that emerged from the Framing concerning the scope of the treaty power and its conflict with Congress's legislative power. These themes were not neatly harmonious, but instead pulled in sometimes contradictory directions. "Globalism" found that several of the leading

37. See Calabresi \& Prakash, supra note 14, at 604-05.

38. See Flaherty, Most Dangerous, supra note 13, at 1774-76, 1787-1801.

39. 1d. at 1810-39.

40. See id. at 1813.

41. Id. at 1816-39. While a supporter of some elements of the unitary executive in the foreign affairs context, see, e.g., John C. Yoo, Federal Courts as Weapons of Foreign Policy: The Case of the Helms-Burton Act, 20 Hastings Int'1 \& Comp. L. Rev. 747, 771-75 (1997) (arguing that the Executive is structurally better suited to the conduct of foreign affairs than the federal judiciary); John C. Yoo, Kosovo, War Powers, and The Multinational Future, 148 U. Pa. L. Rev. (forthcoming 2000) (arguing that unitary Executive precludes delegation of military tactical command to non-U.S. officers) [hereinafter Yoo, Kosovo]; Yoo, New Sovereignty, supra note 2, at 127-28 (arguing that President's authority over law enforcement precludes the delegation of federal authority to international organizations); Yoo, War Powers, supra note 2, at 295-305 (arguing that President has authority to initiate military hostilities unilaterally), and not generally a fan of "fidelity in translation" theory, I thought that Flaherty made some excellent points that had gone unnoticed by other critics of the unitary executive theory. In domestic affairs, however, I admittedly have not been as enthusiastic. See John C. Yoo, The First Glaim: The Burr Trial, United States v. Nixon, and Presidential Power, 83 Minn. L. Rev. 1435, 1469-70 (1999). 
Framers attempted to reconcile this conflict by recognizing Congress's primary role in treaty implementation. This tension had existed in recent Anglo-American political history, and post-ratification events seemed to verify that the Framers' settlement worked in practice. In greater part, the modern doctrine of non-self-execution seeks to honor the Framers' efforts to balance the executive treaty power with the legislature's command over domestic affairs. In hight of the internationalization of affairs and of the explosion in presidential power, the doctrine of non-self-execution amounts to the "translation" of the Framers' balancing efforts to the changed circumstances of today. ${ }^{42}$ "Globalism's" account of the treaty power maintains more fidelity toward those principles of balance and accountability, which Flaherty once believed to be so important for the separation of powers, than "History Right" does.

Aside from these points, I do not want to tax the readers' patience with narrower disagreements with Flaherty's readings of the sources. I would like to identify, however, three interpretive points from which many important consequences flow. First, I do not believe that Professor Flalı erty properly characterizes, or sufficiently appreciates, the lessons of British experience. We both agree that the British experience provides the crucial background against which to measure the Framers' decisions and understandings. It seems to me, however, that when fairly construed, the historical record indicates that Parliament and the Crown did struggle over treaties, Parliament's authority over legislation and funding gave it a check on the Crown's treatymaking powers, the British constitution did not allow treaties to exercise legislative powers, and the Framing generation generally understood this to be the British rule that they had inherited.43 This understanding continued through the Framing Period into the early National Period. ${ }^{44}$ Most writers on foreign affairs agree that non-self-execution was the British rule; what they have failed to appreciate was that it had emerged because of the division of the executive from the legislative power after years of struggle between Parliament and Crown.

Correctly analyzing the background rule established by British practice is not just a nice debating point, but instead bears great importance for the interpretation of subsequent developments. If the British practice stands for the principle that the Executive could not use the treaty power to exercise domestic legislative authority, then the Framers' efforts to

42. The idea that the Framers' efforts can and should be "translated" to contemporary circumstances is known as "fidelity" theory. See Symposium: Fidelity in Constitutional Theory: Editors' Foreword, 65 Fordham L. Rev. 1247, 1247-48 (1997). By pointing out that fidelity theory leads to non-self-execution, I do not mean to signal my agreement with this school of constitutional interpretation.

43. See Yoo, Globalism, supra note 4, at 2048-49, 2072, 2075 n.564 (citing Framers' comments concerning the British rule).

44. See, e.g., Ware v. Hylton, 3 U.S. (3 Dall.) 199, 274 (1796) (opinion of Iredell, J.); 5 Annals of Congress 777 (speech of James Madison on Apr. 6, 1796); Yoo, Globalism, supra note 4 , at $2079-96$. 
continue the British system represented a reconciliation of treaties with legislation in a manner that justifies the modern doctrine of non-self-execution. ${ }^{45}$ Flaherty, however, is forced to read the British experience the opposite way in order to establish a strong presumption that all treaties are self-executing, which cannot be overcome except by constitutional text explicitly adopting the British rule. This presumption allows Flaherty to dismiss as meaningless any predictions and claims during ratification that practice under the American Constitution would mimic or parallel the British system. If Flaherty were correct about British practice, then statements by Framers such as James Wilson, George Nicholas, James Madison and James Iredell, which analogized to the British system in order to explain the constitutional relationship between treaties and legislation, virtually amounted to the eighteenth-century equivalent of static. Only an interpretation of the British rule as one of non-self-execution makes sense of these statements.

Second, Flaherty's account stumbles on the Framers' thinking concerning the separation of powers. Flaherty misconstrues "Globalism's" portrayal of the relationship between the separation of powers and treaties during the Revolution and the Critical Period. According to Flaherty, "Globalism's" most telling mistake is that it "projects a present in which we have internalized separation of powers onto a past that was only just getting around to it." 46 "Globalism," however, does not require the Framers to have adopted a modern separation of powers theory to tell its story. Indeed, its description of events during the colonial and early national periods fits the mixed government model quite well, in that the relationship between the treaty and legislative powers had evolved through practice to form one of the many checks and balances between Crown and Commons. Further, "Globalism" does not argue that the British or colonial and revolutionary Americans had divided the foreign affairs and legislative powers, by function, among several institutions in order to spur

45. While Flaherty is correct to argue that the evolution toward cabinet government in the eighteenth century minimized conflicts between Crown and Parliament, this did not represent a change in the constitutional rule that treaties required legislation to become effective domestically. British practice by the middle of the eighteenth century shows some parliamentary co-operation with the Crown on a regular basis, but this is merely evidence of a political accominodation, rather than a change in the constitution. Further, the evolution toward cabinet government was not immediate, for during the eiglteenth century the Crown continued to choose the ministers of government, who were not selected automatically because they were the leaders of the majority party in Parliament. Thus, conflict between Parliament and the Crown over foreign affairs was still possible, and still occurred. Flaherty's assertions concerning British history fail to explain actual examples where Parliament refused to provide funding or to pass necessary legislation to implement treaties. See Yoo, Globalism, supra note 4, at 2000-06. While Flaherty points to the 1783 Treaty of Paris as an example of the royal exercise of the treaty power that took on legislative functions, the disposition of colonial territory was a disputed question of British constitutional law that was not clearly thought to lie within the legislative power at the time. See Maitland, supra note 35, at 425.

46. Flaherty, History Right, supra note 1, at 2114. 
the modern values of accountability, energy or balance. Instead, "Globalism" explained how the balance between the treatymaking and lawmaking powers had evolved through a history of political struggle. Flaherty's errant salvo fails to address evidence that the colonial assemblies, and later the state legislatures, used their powers over funding and legislation to check foreign affairs decisions with which they disagreed. That evidence proves important, beyond a mere demonstration of legislative checks on the foreign affairs power, because it provided the Framers with a workable model for the treaty power when they did adopt a theory of the separation of powers. ${ }^{47}$

Third, I understand Flaherty to agree with me that the understandings expressed in the state ratifying conventions are far more probative for interpretive purposes than the intentions of the Philadelphia Convention. "Globalism" does not dispute that the drafters of the Constitution rejected a formal role for the House in treatymaking, or that the events of the Federal Convention do not support a thesis of non-self-execution. It does, however, demonstrate that the decision to exclude the Housewhich had nothing to do with a desire to vest the Treaty Clause with elements of the legislative power-provoked substantial alarm among many of the leading Framers, who feared that the state-dominated Senate might use treaties to bargain away vital national interests, and that the House's control over domestic legislation might be undermined. The Constitution reflected the tension between the goal of preventing states from undermining national treaty obligations and the desire of many delegates to establish an independent, but limited, national government. While the Supremacy Clause accomplished the former objective, the Philadelphia Convention did not eliminate the legislature's traditional role in treaty implementation. Instead, it gave the national government a representative Congress that could enforce treaties without state co-operation. To reach a contrary conclusion, one has to make a negative inference that the Framers intended to take a drastic step when they rejected the Wilson and Madison efforts to include the House in treatymaking. ${ }^{48}$ The

47. Flaherty also underestimates the importance of the separation of powers to the Framers during the Revolutionary and Critical Periods. While earlier works on the Constitution's intellectual origins argue that the separation of powers did not fully emerge until 1787, see Wood, supra note 21 , at $446-53$, recent monographs have concluded that the concept had flourished earher, with the writing of the first state constitutions. See, e.g., Adams, supra note 27, at 256-75; Marc. W. Kruman, Between Authority \& Liberty: State Constitution Making in Revolutionary America 109-30 (1997); Forrest McDonald, Novus Ordo Seclorum: The Intellectual Origins of the Constitution 80-86 (1985). While this is not the place to engage in a debate over the separation of powers during the Revolutionary and Critical Periods, to the extent that historians are coming to believe that the separation of powers took hold earlier in the American political consciousness, it is more likely that the Framers would lrave shared the view that the treaty power did not encompass the legislative power's control over domestic regulation.

48. I do not find the Morris amendment on August 23, 1787, as compelling as Professor Flaherty does. See Flaherty, History Right, supra note 1, at 2123-24. I interpret the lack of discussion that accompanied Morris's motion as a sign that the other delegates 
Supremacy Clause, which only addresses the relationship of federal law to state law, would have been an odd way for the Framers to have reversed the legislature's traditional role in treaty implementation, or to have significantly altered the division of the treatymaking from the lawmaking power.

"Globalism's" main methodological point, however, is that the records of the state ratifying conventions, which had gone untapped by internationalists, should hold greater sway than those of the Philadelphia Convention. It was at these conventions, despite Flaherty's best efforts to read the evidence to the contrary, where Federalists relied upon the House's role in treaty implementation to calm fears that the President and Senate might exercise legislative authority in the guise of a treaty. As for Flaherty's arguments about specific Framing evidence, such as proposed state amendments or different convention speeches, constraints of time and space prevent a full reply. I would note, however, that many of Flaherty's claims were made by supporters of the Jay Treaty during the House debates on implementation. Significantly, the chief participant in the Philadelphia Convention, the state ratification debates, and the Jay Treaty fight publicly rejected this interpretation of the ratification. Responding to claims that the Pennsylvania, Virginia and North Carolina convention records supported a theory of self-execution, James Madison asked whether

it did not appear from a candid and collected view of the debates in those conventions, and particular in that of Virginia that the treatymaking power was a limited power; and that the powers in our constitution, on this subject, bore an analogy to the powers on the same subject, in the government of G. Britain. 49

Madison then went on to explain, in reasoning and judgment similar to "Globalism," why a self-execution approach to the treaty power mis-

considered his proposal to be stylistic only, while Flaherty reads this fairly significant step as receiving such widespread unanimity as to require no debate. The himited import of the amendment is demonstrated by the lengthy debate that occurs, at approximately the same time in the Convention, over the substantive efforts by Wilson and Madison to provide the House with a formal role in treatymaking. Further, Morris's proposal sought to amend not the Treaty or Supremacy Clauses, but Congress's authority to call out the militia to enforce federal law, which only underscores the Framers' behief that the political branches, particularly Congress, would be responsible for treaty implementation. Certainly other Framers later did not find Morris's amendment to be as significant as Flaherty does. In rejecting the request for the Jay Treaty negotiating papers, for example, President Washington failed to mention Morris's amendment, even as he relied upon the Convention's rejection of the Wilson and Madison proposals. See Yoo, Globalism, supra note 4 , at $2089 \&$ n.630. Hamilton suggested that Washington make reference to the Philadelphia Convention's rejection of the Madison and Wilson amendments in his reply to the House, but he did not mention the alteration of the militia clause. See Alexander Hamilton to President Washington, Mar. 29, 1796, in 20 Papers of Hamilton 100 (Harold C. Syrett ed., 1962) [hereinafter "Hamilton Papers"].

49. James Madison, Speech of Apr. 6, 1796, Madison Papers, supra note 17, at 296. 
read various framing sources. ${ }^{50}$ When it comes to choosing between internationalist law scholars and Madison, 1 will take Madison.

\section{Textual and Structural Problems with Self-Execution}

In contrast to Flaherty, Professor Vázquez takes a decidedly non-historical approach. His Response boils down into two points: first, that the text of the Supremacy Clause forecloses any possibility that treaties might be non-self-executing; and second, that "Globalism" is unclear about what non-self-execution is and how it would apply in court.

In general, Vázquez, engages in a simplistic reading of the Supremacy Clause and ignores more important textual provisions and structures. Reading the Supremacy Clause to permit non-self-execution not only allows different provisions of the Constitution to be read in harmony, it also respects the constitutional goal of a national government of limited powers. Non-self-execution promotes political democracy by infusing foreign policymaking with House participation, without sacrificing secrecy and dispatch. It ensures that the same lawmaking process applies to laws that have the same effect in regulating the domestic conduct of private parties. Finally, non-self-execution honors the Constitution's primary allocation of foreign affairs authority to the political branches, while also recognizing the functional difficulties experienced by courts in this area. A detailed exposition of these arguments is outside the scope of this Rejoinder. In the next few sections, $\mathrm{I}$ briefly sketch the arguments and conclude that Vázquez's Response to "Globalism" glosses over significant textual and structural problems with self-execution.

\section{A. Reading the Constitution in Harmony}

Vázquez relies on the text of the Supremacy Clause to defend his claim that treaties are self-executing. He writes that non-self-execution would "have the unfortunate effect of reading the reference to treaties entirely out of the Supremacy Clause." Yet the scope of Vázquez's inquiry is too narrow; he does not account for the actual language of the Supremacy Clause, nor does he consider it in the context of other critical provisions of the Constitution. As I argue below, self-execution would have the unfortunate effect of reading out of our Constitution important aspects of the separation of powers and federalism, and would also undermine the principle of popular sovereignty. The doctrine of self-execution vests in the executive branch a legislative power that is broader in scope than that enjoyed by Congress. Self-executing treaties arguably are free of the constraints of federalism and the separation of powers-threatening to disrupt our constitutional structure. Non-self-execution, in contrast, harmonizes the relevant constitutional clauses, and maintains the important distinction between foreign relations and domestic lawmaking.

50. See id. at 294-301. 
Vázquez's theory of self-execution would distort an executive power into a legislative one. Article II, Section 1 provides that the "executive Power shall be vested in a President of the United States." As Justice Scalia has written, this "does not mean some of the executive power, but all of the executive power." 51 Others also read Article II to constitute a broad grant of power, analogizing it to Article III's Vesting Clause, which is the only textual source for the federal judiciary's powers. ${ }^{52}$ The powers enumerated in Section 2, such as command of the military, pardons and execution of the laws, are executive in nature. Section 2 defines the broad grant of executive power to the President-it does not create new executive-legislative powers. ${ }^{53}$ By its placement in Article II, therefore, treatymaking is clearly an executive power.

To be sure, the Constitution does not embody a pure separation of powers in which each branch solely exercises all functions peculiar to it. Nonetheless, the Senate's participation in treatymaking and appointments reflects the Framers' effort to dilute the unitary nature of the executive branch in those areas, rather than to transform these functions into legislative powers. While the Constitution reduces executive power in favor of the legislature, it does not transfer what were considered legislative powers to Article II. When the Constitution grants the executive a power that is legislative in nature, such as the veto power, it does so in Article I, not in Article II, because Article I alone describes the finely balanced method for making federal laws. ${ }^{54}$ The Constitution centralizes public lawmaking into a tortuous process to make the exercise of legislative authority more difficult, thereby protecting the states and the people from unwarranted exercises of federal power. ${ }^{55}$ In the few cases articulat-

51. Morrison v. Olson, 487 U.S. 654, 705 (1988) (Scalia, J., dissenting).

52. See, e.g., Calabresi \& Prakash, supra note 14, at 570-71 (arguing that the linguistic similarity between the vesting clause of Article II and Article III suggests Article II should be read as a general grant of power). On the judiciary's inherent powers and the vesting clause, see Akhil R. Amar, A Neo-Federalist View of Article III: Separating the Two Tiers of Federal Jurisdiction, 65 B.U. L. Rev. 205, 229-30 (1985) [hereinafter Amar, NeoFederalist View]; Jolin C. Yoo, Who Measures the Cliancellor's Foot?: The Inherent Remedial Authority of the Federal Courts, 84 Cal. L. Rev. 1121, 1144-51 (1996).

53. See Calabresi \& Prakash, supra note 14, at 578-79. This was a point first made by Alexander Hamilton in his "Pacificus" replies defending the constitutionality of President Washington's Neutrality Proclamation. See Pacificus No. 1, June 29, 1793, reprinted in I5 Papers of Hamilton, supra note 48 , at 39 .

54. While no one can deny that the executive branch also makes law through administrative regulations, this occurs due to the delegation of authority by Congress, subject to clear and manageable standards, rather than by direct constitutional authorization. See, e.g., Clinton v. New York, 524 U.S. 417 (1998), Mistretta v. United States, 488 U.S. 361,372 (1989). Of course, whether the "intelligible principle" standard of these cases actually imposes a real check on executive discretion in public adininistration is another question. See Edward L. Rubin, Law and Legislation in the Adininistrative State, 89 Colum. L. Rev. 369, 380-85 (1989).

55. See, e.g., Immigration \& Naturalization Serv. v. Chadha, 462 U.S. 919, 959 (1983) ("The choices we discern as having been made in the Constitutional Convention impose burdens on governmental processes that often seem clumsy, inefficient, even unworkable, 
ing the distinction between legislative and executive power, the Supreme Court has defined the executive power by its very lack of the power to make laws. ${ }^{56}$

Moreover, self-execution invites a conflict between the textual grants of the executive and legislative powers and resolves the clash by allowing the treatymaking authority to trump Congress's Article I powers. According to internationalists, the President and Senate may resort to the treaty process to address any matter, so long as it is "an agreement between two or more states or international organizations that is intended to be legally binding and is governed by international law." ${ }^{\text {27 }}$ If treaties enjoy this

but those hard choices were consciously made by men who had lived under a form of government that permitted arbitrary governmental acts to go unchecked."). Hence Article I declares that "[a]11 Legislative Powers herein granted shall be vested in a Congress of the United States," and nowhere else. U.S. Const. art. I, $\$ 1$. One might argue that Article I's use of the phrase "herein granted" allows for a dispersal of federal lawmaking authority not enumerated in Article $\mathrm{I}$. But that phrase is better read as a federalism provision giving to Congress all of the legislative power that the people have enumerated in the Constitution, rather than all of the legislative power in the people's possession. See Myers v. United States, 272 U.S. 52, 128 (1926); see also Calabresi \& Rhodes, supra note 14, at 1175-76 (finding that Congress's legislative power is limited to specifically enumerated powers "herein granted" by the Constitution). Recall that Hamilton defined the executive power in The Federalist as "the execution of the laws and the employment of the common strength," which, he believed, "seem to comprise all the functions of the executive magistrate," as distinguished froin the legislative power, "the essence" of which "is to enact laws, or in other words to prescribe rules for the regulation of the society." The Federalist No. 75, N.Y. Indep. J. (Mar. 26, 1788), reprinted in 16 The Documentary History of the Ratification of the Constitution 481, 482 (John P. Kaminski \& Gaspare J. Saladino eds., 1986).

56. "In the framework of our Constitution," Justice Black wrote for the Court in Youngstown Sheet $\mathcal{E}$ Tube Co. v. Sawyer, "the President's power to see that the laws are faithfully executed refutes the idea that he is to be a lawmaker." 343 U.S. 579,587 (1952). Whether one believes in a "law-enforcement," a "protective power," Henry P. Monaghan, The Protective Power of the Presidency, 93 Colum. L. Rev. 1 (1993), or a broader inherent power model of the presidency, see Calabresi \& Prakash, supra note 14, none of these theories recognize an executive authority to legislate upon the legal rights and duties of American citizens. Treaty self-execution, however, would allow the executive branch to wield legislative power and to directly regulate the domestic conduct of private parties. The constitutional text resists the notion that an "independent, free-standing presidential law-making authority exists insofar as the riglts of American citizens are concerned." Monaghan, supra, at 4.

57. Lori F. Damrosch, The Role of the United States Senate Concerning "SelfExecuting" and "Non-Self-Executing" Treaties, 67 Chic.-Kent L. Rev. 515, 530 (1991) ("[O]ur constitutional law is clear: the treaty-makers may make supreme law binding on the states as to any subject, and notions of states' rights should not be asserted as impediments to the full implementation of treaty obligations."); see also Henkin, supra note 5, at 191 (on the attempt to limit treaties to matters of "international concern," observing "I know of no basis for reading into the Constitution such a limitation on the subject matter of treaties. Nor would I know any formula for determining which matters are and which are not our 'busmess' or the proper "business' of other countries."); Gerald L. Neuinan, The Global Dimensions of RFRA, 14 Const. Commentary 33, 34, 46-47 (1997). According to Henkin, "[i]f there are reasons in foreign policy why the United States seeks an agreement with a foreign country, it does not matter that the subject is 
broad scope, and if, as Vázquez argues, they are always self-executing, then the treatymakers can regulate any area that lies within Article I's enumerated powers. For example, a self-executing treaty could make certain actions federal crimes, despite the Constitution's allocation to Congress of authority to "define and punish Piracies and Felonies committed on the high Seas, and Offences against the Law of Nations."58 Likewise, the treatymakers would be free to establish new commercial or environmental regulations, though the power to regulate interstate commerce is vested in Congress. If the United States forges multilateral agreements addressing problems that were once domestic in scope, treaties could replace legislation as a vehicle for domestic regulation.

Recognizing these problems, the Restatement and leading internationalist scholars admit that certain exceptions must exist from their general principle. For example, the Restatement declares that treaties cannot take direct effect as American law if legislation is "constitutionally required."59 Yet internationalists argue that the treatymakers can exercise the Commerce Clause power, among others, without resorting to statute. ${ }^{60}$ If Vázquez is correct that the treatymakers can exercise a single Article I, Section 8 power granted to Congress, then the treatymakers must be able to exercise all of Congress's legislative powers. The constitutional text, which treats all of these powers in Article I, Section 8, does not make any distinctions among them. ${ }^{61}$ Internationalists concede that legislation may be necessary to implement a treaty if it calls for a declaration of war, an appropriation of money, the raising of taxes, or the punishment of criminal conduct. ${ }^{62}$ Yet, neither the Restatement nor internationalists provide any principled distinctions between those areas that can be the subject of treaties, and those areas that cannot be. As Madison argued during the Jay Treaty debates, "if the Treaty-power alone could perform any one act for which the authority of Congress is required by the Constitu-

otherwise 'international,' that the treaty 'makes laws for the people of the United States in their internal concerns,' or that-apart from treaty-the matters is 'normally and appropriately . . . within the local jurisdictions of the States." Id. at 197.

58. U.S. Const. art. I, $\S 8$.

59. Id. at $\$ 111(4)$.

60. See Henkin, supra note 5, at 194-95.

61. The one exception is the Appropriations Clause, which declares that "[n]o money shall be drawn from the Treasury, but in Consequence of Appropriations made by Law." U.S. Const. art. I, \$9, cl. 7. Professor Henkin and the Restateinent admit that use of the term "by Law" indicates that appropriations can only be made by a statute, rather than by a treaty. See Restateinent, supra note 57 , at $\$ 111 \mathrm{cmt}$. i; Henkin, supra note 5, at 203. Yet this reading undermines their approach to the Supreinacy Clause, which is built on the idea that a treaty is the constitutional equivalent of a "Law." See, e.g., Vázquez, TreatyBased Rights, supra note 3, at 1146-55.

62. See, e.g., Restatement at $\$ 111 \mathrm{cmt}$. i \& reporter's note 6 ; Henkin, supra note 5 , at 203. 
tion, it may perform every act for which the authority of that part of the Government is required."63

In making treaties self-executing, Vázquez and other internationalists would create a potentially limitless legislative power. While Article I, Section 8 , vests Congress with enumerated plenary powers, the Constitution subjects these grants to the limitations of Article I, Section 9.64 Even some important elements of the Bill of Rights apply textually only to Congress. If Vázquez is right that the treatymakers can exercise legislative power without resort to Article I's lawmaking process, then self-execution allows the federal government to legislate without opposition from the textual checks on congressional powers. As Madison worried, "if the legislative powers specifically vested in Congress, are to be no limitation or check to the Treaty power, it was evident that the exceptions to those powers, could be no limitation or check to the Treaty power."65 While the Supreme Court has rejected the argument that treaties can infringe on individual rights, ${ }^{66}$ textually the Constitution would seem to permit this result, once we agree with Vázquez that treaties are self-executing.

Self-execution also may permit the treatymakers to act outside the constraints of the separation of powers, which internationalists believe do not apply to treaties. ${ }^{67}$ If they are right, the treatymakers could delegate to international organizations powers that ordinarily inhere in the executive branch, such as authority over law enforcement or administrative rulemaking. ${ }^{68}$ Or a treaty could transfer authority from Congress to the executive branch or to an international organization, as some argue that the U.N. Charter actually does, when a statute could not. ${ }^{69}$ According to 258.

63. James Madison, Jay's Treaty (Mar. 10, 1796) in Madison Papers, supra note 17, at

64. While most of the provisions of Article I, Section 9 are written in the passive tense, they seem to apply only to Congress. The first clause of Article I, Section 9, is written as a prohibition on Congress, and Section 9 is included in Article I only. This of course raises the constitutional problem whether the President can act in ways that violate Article I, Section 9, such as President Lincoln's suspension of habeas corpus, which this article cannot hope at this point to address. It should be noted that Madison appeared to believe that Article I, Section 9 applied only to Congress. See id. at 259.

65. ld.

66. See Reid v. Covert, 354 U.S. 1 (1957) (plurality opinion).

67. See, e.g., Henkin, supra note 5, at 194-96 (arguing that treaties have historically regulated in areas where House has legislative authority). Henkin concedes that while the Treaty Power "is not limited by the powers of Congress, ... . it is assumed to be subject to other radiations from the separation of powers." Id. at 195. He does not, however, identify any separation of powers principles that would check the Treaty Power, aside from the admittedly "hypothetical" possibility that a treaty would redistribute wholesale certain powers among the three branches. Id. at 195-96.

68. See id. at 196 (maintaining even that a treaty could "bargain away" Congress's authority to declare war by allowing war to be triggered automatically under certain events).

69. See, e.g., Thomas M. Franck \& Faiza Patel, UN Police Action in Lieu of War: "The Old Order Changeth," 85 Am. J. Int'l L. 63, 65-70, 73-74 (1991) (arguing that under U.N. Charter, when President acts to deploy armed forces under authorization of Security 
internationalist logic, the treatymakers could delegate lawmaking or lawexecution authority from the national government to international agencies in ways that would violate either the Appointments Clause, the vesting clauses, or the non-delegation doctrine, if a statute were used. ${ }^{70}$ If treaties are interchangeable with statutes as domestic law, as Vázquez would have it, but are free from the usual structural constraints of the separation of powers, then the treatymakers could restructure government to regulate domestic affairs in ways not permitted to Congress.

Self-execution also would free the treatymakers from federalism limitations, which internationalists claim do not apply to treaties. Leading commentators assert that the President and Senate can make policy for the whole nation on any subject, regardless of the limited enumeration of federal powers or the Tenth Amendment. ${ }^{71}$ The Tenth Amendment presents no bar, these authorities argue, because its reservation of powers is inapplicable to the treaty power, which was expressly delegated to the federal government. Anything that the treaty power can touch upon is, by definition, excluded from the Tenth Amendment. ${ }^{72}$ In Missouri v. Hol land, ${ }^{73}$ the Supreme Court suggested its agreement with this proposition. According to an opinion by Justice Holmes, the treaty power was not to be limited in the same manner as Congress's Article I, Section 8 powers, because treaties concerned "a national interest of very nearly the first magnitude," the power over which had to be vested somewhere in the national government. ${ }^{74}$ Holland's expansive reading of the treaty power's scope underscores the severe textual and structural difficulties created by

Council, Congress need not be consulted). But see Michael J. Glennon \& Allison R. Hayward, Collective Security and the Constitution: Can the Commander in Chief Porwer Be Delegated to the United Nations?, 82 Geo. L.J. 1573, 1587-1601 (1994) (calling into doubt whether Constitution permits President to delegate Commander in Chief power to foreign body, and whether Congress may delegate its power to declare war to President of foreign body); see also Yoo, Kosovo, supra note 41 (arguing that treaties cannot alter domestic separation of powers governing warmaking, but that President already possesses authority to initiate military hostilities unilaterally).

70. See generally Yoo, New Sovereignty, supra note 2, at 96-116 (arguing that Court's approach to Appointments Clause, text and history of provision, and structure of Constitution all reflect principle of government accountability).

71. See, e.g., Restatement, supra note 57, at $\$$ 302-303 ("Tenth Amendment . . . does not limit the power to make treaties or other agreements); Henkin, supra note 5 , at 190-93 (claiming that Court has repeatedly rejected argument that treaties cannot deal with matters reserved to the states through constitutional scheme and Tenth Amendment).

72. See Henkin, supra note 5, at 191. This argument, Henkin tells us, is "clear and indisputable." Id.

73. 252 U.S. 416, 433-35 (1920). Holland raised the question whether Congress had authority to enact the Migratory Bird Treaty Act of 1918, which implemented a 1916 treaty between the United States and Great Britain that protected migratory birds. The treaty barred the hunting or capture of any of the birds protected by the treaty, an action that the federal courts at the time had held lay outside Congress's Commerce Clause powers. See id. at 432 (citing lower court decisions).

74. Id. at 435 . 
Vázquez's theory of self-execution. ${ }^{75}$ When combined with Vázquez's claims that all treaties have the same legal force as statutes, that they automatically preempt inconsistent state law, and that they are to be immediately enforced by the federal and state courts, the treaty power becomes an unlimited authority to legislate on any subject. ${ }^{76}$

75. Holland makes sense because the treaty power is an executive power located in Article II, which is not subject to the textual limitations that apply to Article I. This becomes an enormous loophole if the treatymakers can exercise legislative power that is free from subject-matter limitations.

76. I am not arguing that federalism limits must apply to the Treaty Clause in the same manner that they apply to congressional statutes. (Curtis Bradley, however, makes some powerful arguments toward that end. See Bradley, supra note 15, at 433-50.) Rather, I am making the point that internationalist doctrine on the scope of treaties produces a legislative power that goes well beyond Congress's Article I grants, when combined with Missouri v. Holland's treaty theory, on the one hand, and Vázquez's theory of self-execution on the other. Madison, for one, believed that an interpretation of the treaty power that promoted balance ought to be favored over one, such as that promoted by internationalists, that was virtually limitless. "The Constitution of the U. States is a Constitution of limitations and checks," Madison declared during the Jay Treaty debates. James Madison, Jay's Treaty (Mar. 10, 1796) in Madison Papers, supra note 17, at 261. "The powers of the [federal] Government had been further divided into three great Departments; and the Legislative department again subdivided into two independent branches." Id. These powers themselves were subject to "exceptions and qualifications," according to Madison, "as additional guards against the abuses to which powers is liable." Id. Reading the Treaty Clause expansively, he argued, frustrated this constitutional goal. "With a view to this policy of the Constitution, it could not be unreasonable, if the clauses under discussion were thought doubtful, to lean towards a construction that would limit \& controul the Treaty-making power, rather than towards one that would make it omnipotent." Id.

The expansive breadth of the Treaty Power can be further seen in light of the latest line of Supreme Court cases on federalism. In a series of recent decisions, the Court has attempted to identify a core of state sovereignty that remains immune from federal power. See, e.g., Alden v. Maine, I19 S. Ct. 2240, 2246-69 (1999) (protecting states from suit in state court); Printz v. United States, 521 U.S. 898, 935 (1997) (prohibiting congressional action that compels state officers to execute federal law); Seminole Tribe v. Florida, 517 U.S. 44, 57-73 (1996) (limiting Congress's power to abrogate state sovereigu immunity in federal court); United States v. Lopez, 514 U.S. 549, 558-68 (1995) (limiting Congress's commerce power); New York v. United States, 505 U.S. 144, 161-66 (1992) (prohibiting Congress from commandeering states into the services of federal regulation); Gregory v. Ashcroft, 501 U.S. 452, 456-64 (1991) (requiring clear congressional intent to regulate state employees); see also John C. Yoo, The Judicial Safeguards of Federalism, 70 S. Cal. L. Rev. 1311, 1334-57 (1997) (arguing that Court's recent jurisprudence has attempted to draw clear lines between enumerated powers of federal government and sovereignty of the states). Under internationalist theories, however, state sovereignty cannot escape the treaty power, even though it cannot be regulated by Congress's Article I, Section 8 powers. An internationalist would argue that international agreements easily preempt state policy choices, even those involving the sovereiguty of the state itself. See, e.g., Lori Fisler Damrosch, The Justiciability of Paraguay's Claim of Treaty Violation, 92 Am. J. Int'l L. 697, 702-03 (1998) (arguing Eleventh Amendment "should be construed as providing federal fornm for enforcing treaty obligation against state officials," and Court should undertake "searching scrutiny" of state actions affecting U.S. foreigu relations); Jordan J. Paust, Breard and Treaty-Based Rights Under the Consular Convention, 92 Am. J. Int'l L. 691, 696 (1998) (arguing that "the absolute supremacy and reach of treaties to the states under 


\section{B. Self-Execution and the Public Lawmaking Process}

Self-executing treaties conflict not just with the constitutional text and the structure of our government, but also with the principle of popular sovereignty underlying the Constitution. In almost all domestic spheres of activity over which the federal government has jurisdiction, the Constitution grants the power to legislate to Congress. As a matter of accountability, when the government imposes rules of conduct on individuals, those rules ought to be made by members of the legislature who directly represent the people. ${ }^{77}$ Non-self-execution, therefore, better promotes democratic government in the lawmaking process by requiring the consent of the most directly democratic part of the government, the House of Representatives, before the nation can implement treaty obligations at home. To be sure, the President provides a safeguard against an anti-majoritarian treaty, 78 but presidential participation is not a complete protection for majority rule, especially during a second term. Establishing a process in which the House takes part through implementing legislation provides yet another safeguard for popular sovereignty. ${ }^{79}$

Non-self-execution also produces benefits for the system of public lawmaking described by different theories of the legislative process. Some students of legislation believe that Congress primarily acts as a forum for the making of deals between interest groups. ${ }^{80}$ Although some

Article VI should condition the meaning of the Eleventh Amendment"). Or take the example of Congress's enforcement powers under the Fourteenth Amendment. In City of Boerne v. Flores, 521 U.S. 507, 516-29 (1997), and Florida Prepaid Postsecondary Educ. Expense Bd. v. College Sav. Bank, 119 S. Ct. 2199, 2204-1I (1999), the Court declared that Congress cannot use its powers under Section 5 of the Fourteenth Amendment to redefine and enforce new rights that contradict the Supreme Court's interpretation of Section 1 of the Amendment. No such limitations apply to the treatymakers, which raises the possibility that if treaties are self-executing, the treatymakers can create new individual rights enforceable against the states even when Congress, acting by statute, cannot. See Gerald L. Neuman, The Global Dimensions of RFRA, 14 Const. Commentary 33 (1997).

77. Cf. Akhil Reed Amar, Of Sovereignty and Federalism, 96 Yale L.J. 1425, I429-66 (1987) (arguing that true sovereignty lies with the people of the United States and that therefore all government must be limited).

78. See Yoo, Globalism, supra note 2, at 1962, 2038-39.

79. While perhaps unlikely, it is possible under the treaty process for two-thirds of the Senate, with the co-operation of a second-term President or a President uninterested in reelection, to force the nation to enter into a treaty without the support of the majority of the people. According to 1998 population estimates, two-thirds of the Senate can represent as little as 32 percent of the population. According to the Bureau of the Census, in 1998 the sixteen most populous states were (in millions of people): California 32.7; Texas 19.7; New York 18.2; Florida 14.9; Illinois 12.0; Pennsylvania 12.0; Ohio 11.2; Michigan 9.8; New Jersey 8.1; Georgia 7.6; North Carohina 7.5; Virginia 6.8; Massachusetts 6.1; Indiana 5.9; Washington 5.7; Missouri 5.4. See Population Division, U.S. Bureau of the Census, State Population Estimates and Demographic Components of Population Change, July 1, 1997-July 1, 1998 (visited Oct. 15, 1999) <http://www.census.gov/population/ estimates/state>.

80. See, e.g., James M. Buchanan \& Gordon Tullock, The Calculus of Consent: Logical Foundations of Constitutional Democracy 283-295 (1965) (discussing the important role of "pressure groups" in the promotion of economic interest); Mancur 
public choice scholars are dubious that the legislative process advances the "public interest," pluralists view interest groups as desirable because they facilitate stability, moderation, and broad satisfaction with the political system. ${ }^{81}$ Other theories of the legislative process suggest that if international agreements are implemented by the full Congress, more committees and groups will become involved, bringing to bear greater legislative and policy expertise, producing more information on legislative choices, and fostering communication between the different political players. ${ }^{82}$ The more steps that exist in implementing treaties, the more open the process and the greater the chances for reasoned discussion about the policies involved. ${ }^{83}$ A requirement that treaties receive implementing legislation exposes international agreements to the benefits of a more open political process, which promotes stable policymaking and broader political acceptance.

Invoking the words of the Framers, 84 Vázquez and other internationalists argue that the House is ill-suited for the secrecy needed for diplomacy. These secrecy concerns no longer seem compelling, due to the large size of the Senate, the role of the House in foreign affairs, and the nature of modern regulatory treaties, which resemble domestic legislation in purpose and effect. ${ }^{85}$ Furthermore, the Senate never assumed the

Olson, The Logic of Collective Action: Public Goods and the Theory of Groups 132-67 (1965) (discussing the theory of "special interests" and incentives to organize for the common benefit); William H. Riker, Liberalism Against Populism: A Confrontation Between the Theory of Deinocracy and the Theory of Social Choice 169-212 (1982) (discussing the theory of Social Choice and changes of the political agenda).

81. See, e.g., William N. Eskridge, Jr. \& Philip P. Frickey, Cases and Materials on Legislation: Statutes and the Creation of Public Policy 49-50 (2d ed. 1994) (discussing public choice theory and the creation of "models that treat the legislative process as a microeconomic system"); Theodore Lowi, The End of Liberalism 52-56 (2d ed. 1979) (interest group liberalisin is thought to settle conflicts in society).

82. See generally Keith Krehbiel, Information and Legislative Organization (1991) (proposing a link between distributive and informational theories of legislative organization); Arthur Maass, Congress and the Common Good (1980) (discussing the relationship between political institutions, public opinion, political actors and elections); William N. Eskridge, Overriding Supreme Court Statutory Interpretation Decisions, 101 Yale L.J. 331, 356-57 (1991) (discussing information theory and the creation of public policy).

83. Cf. Cass Sunstein, Interest Groups in American Public Law, 38 Stan. L. Rev. 29, 33-35 (1985) (addressing the problem of factionalism in supplanting political discussion and debate).

84. See, e.g., The Federalist No. 75, at 483 (Alexander Hamilton), in 16 Documentary History, supra note 55 (explaining exclusion of House fron formal role in treatymaking).

85. As the niodern Senate numbers about $50 \%$ niore inembers than the first House of Representatives, it no longer reflects the small numbers that the Framers believed necessary for diploinacy. Incumbency retention rates in the House, which regularly reach 90 percent, see Norman Ornstein et al., Vital Statistics on Congress, 1998-1999, 47-9, 64-5 (1998), also suggest that the House enjoys nore stability, particularly in its coinmittees and leadership, than the Framers anticipated. The House today plays an equal role in foreign policy, with committees on international relations, national security, and intelligence, that routinely handle sensitive information and oversee legislation related to foreign affairs. 
active role in diplomatic negotiations that some Framers may have hoped for. ${ }^{86}$ The Senate's formal role in treatymaking has become one of afterthe-fact consent, while the President assumes primary responsibility for setting foreign policy and conducting diplomatic negotiations.

Giving treaties self-executing effect distorts the public lawmaking process by removing the procedural checks on the exercise of legislative authority. In place of the parallel House and Senate procedures for studying and adopting legislation, in which the President exercises a final veto, the treatymaking process shifts the center of policymaking from Congress to a President unencumbered by bicameralism. The development of treaty provisions and the understanding of treaty negotiation and drafting is dominated by the President, rather than by the legislature, as would be the case with domestic statutes. The termination of treaties also demonstrates how treaties would distort the public lawmaking process. Statutes require the consent of both houses of Congress and the President, or two-thirds of Congress without the President, before they can be repealed. Although the Constitution is silent on the question, and even though it once was thought that breaking treaties required the consent of two-thirds of the Senate, ${ }^{87}$ today most commentators, courts and government entities accept that the President unilaterally may terminate treaties. ${ }^{88}$ As with treaty formation, the President retains this authority due to his preeminent position in foreign affairs and his structural superiority in managing international relations. If the nation regulates certain domestic conduct by statute, the President cannot terminate the rules without congressional approval. If the nation should regulate the same conduct by treaty, however, the President may terminate the regulation at will.

Furthermore, under the consensus view, the "last-in-time" rule allows treaties to supersede earlier statutes, and subsequent statutes to override

Even if the Senate is better disposed to diplomacy than the House, multilateral treaties that impose domestic rules of conduct do not demand secrecy or speed of action. Only those treaties that have the least domestic effect, and hence need no implementing legislation, such as military or political alliances, demand secrecy. A presumption of non-selfexecution would not impact the nation's ability to negotiate these types of treaties.

86. See Stanley Elkins \& Eric McKitrick, The Age of Federalism 55-58 (1993) (describing President Washington's failed attempt to consult with the first Senate on treaties). Apparently, when President Washington appeared in the Senate, the noise and confusion led to the treaty matter being deferred to another day. President Washington left in a huff, and according to one story declared that "he would be damned if lie ever went there again." Id. at 55.

87. See, e.g., Stefan Riesenfeld, The Power of Congress and the President in International Relations: Three Recent Supreme Court Decisions, 25 Cal. L. Rev. 643, 655-68 (1937) (discussing the constitutionality of congressional abrogation of a treaty).

88. See, e.g., Goldwater v. Carter, 617 F.2d 699, 708-09 (D.C. Cir. 1979) (affirming Presidents' unilateral power to terminate treaty); Restatement, supra note 57 , at $\$ 339$ (affirming the President's power to terminate treaties under the general "constitutional authority for the President to conduct the foreign relations of the United States"); Henkin, supra note 5, at 214 (discussing widespread acceptance of the President's power to "denounce or otherwise terminate a treaty"). 
earlier treaties. ${ }^{89}$ In other words, if the terms of a statute and of a treaty come into conflict, the provision that was enacted most recently will preempt the earlier version. Allowing treaties and statutes to supersede each other in this way seems inconsistent with the formalist approach to lawmaking articulated by the Supreme Court in I.N.S. v. Chadha.90 In Chadha, the Court invalidated Congress's creation of the legislative veto, which was used in that case to overturn the Attorney General's determination, pursuant to his statutorily delegated power, not to deport an alien. It reasoned that Congress could enact legislation-which it defined as legislative action affecting the rights of individuals outside of Congress ${ }^{91}$ - only by passing laws that survived bicameralism and presentment to the President. ${ }^{92}$ A decision to repeal earlier legislation-as was the case with the use of the legislative veto in Chadha-requires a new law. Viewed in Chadha's light, the last-in-time rule violates the Constitution's structural primciples of lawmaking, because it allows the treatymakers to counteract an earlier action by the President, Senate, and House. During the Jay Treaty debates, Madison rejected this possibility out of hand because "it involved the absurdity of an Imperium in imperio; or of two powers both of them supreme, yet each of them liable to be superseded by the other." ${ }^{\text {93 }}$

89. See Whitney v. Robinson, 124 U.S. 190, 194 (1888); see also The Chinese Exclusion Case, 130 U.S. 581, 600 (1889) ("the last expression of the sovereign will must control"); Head Money Cases, 112 U.S. 580, 599 (1884) (holding that a treaty does not have "superior sanctity" to a statnte by nature); Henkin, supra note 5, at 209-11 ("At the end of the twentieth century, the power of Congress to enact laws that are inconsistent with U.S. treaty obligations, and the equality of treaties and statutes in domestic U.S. law, appear to be firmly establislied."). This doctrine was dramatically placed on display in Breard v. Greene, in which a Paraguayan national claimed that his execution by the state of Virginia violated his treaty riglits. 523 U.S. 371,373 (1998). The defendant claimed that under the Vienna Convention on Consular Relations he should have received the opportunity to consult with Paraguayan consular officials upon his arrest. See id. Although American lower courts rejected his habeas petition because it was procedurally barred, the International Court of Justice found that sufficient grounds existed to hear the case and ordered the Umited States to "take all measures at its disposal" to stay the execution. Id. at 374. The Supreme Court refused to issue a stay of the execution. Even assuming that the defendant liad a right under the Vienna Convention, the Court held, such provisions of the treaty were superseded by the Antiterrorism and Effective Death Penalty Act of 1996, which codified the Court's case law barring federal habeas claims that were not first made to the state courts. See id. at 376. Not surprisingly, Breard has received extensive criticism from internationalists. See, e.g., Jonathan I. Cliarney \& W. Michael Reisman, Agora: Breard, 92 Am. J. Int'l L. 666 (1998).

90. 462 U.S. 919 (1983).

91. See id. at 952 .

92. See id. at 958.

93. James Madison, Speech on Jay's Treaty (Mar. 10, 1796), in Madison Papers, supra note 17, at 257. Although Madison admitted that the Roman constitution had operated similarly, he believed that it was only "a political phenomenon, which had been celebrated as a subject of curious speculation only, and not as a model for the imstitutions of any other Country." Id. In Madison's mind, vesting the legislative power in two separate authorities 


\section{Self-Execution and Judicial Enforcement of Federal Law}

Vázquez and other internationalists further err in assuming that all provisions of federal law are self-executing. Their logic falters because courts have refused to adopt the same blanket rule of self-execution for constitutional and statutory provisions that internationalists urge for treaties. In the statutory context, federal courts generally have refused to recognize a claim, even when brought by an injured plaintiff, unless the statute clearly grants a private cause of action. ${ }^{94}$ Although the Court once adopted a generous approach toward the implication of private rights of action, ${ }^{95}$ it since has employed a narrower approach that requires an expression of congressional intent in either the statutory text or the legislative history. ${ }^{96}$ The Court's strict test on private rights of action means that numerous federal statutory provisions cannot be enforced in court. Administrative law schemes recognize that certain federal mandates are

that could each "annul the proceedings of the other" would produce only an unstable and irrational government. Id.

Professor Vázquez places great store in the last-in-time rule as proof of the interchangeability of treaties and statutes in regulating domestic conduct. According to Vázquez, the fact that treaties can override previously-enacted statutes demonstrates that treaties are laws of the land that have the same domestic effect as statutes. See Vázquez, Laughing at Treaties, supra note 3, at 2189-90. He beheves the rule to be "entrenched." Id. On closer examination, however, the last-in-time rule actually serves as a repudiation of internationalist theory. In addition to Breard, the Supreme Court regularly has given effect to statutes that are inconsistent with earlier treaty obligations. See, e.g., The Chinese Exclusion Case, I30 U.S. 58I, 600 (1889) (affirming Congress's power to pass legislation conflicting with treaty stipulations); Whitney v. Robertson, 124 U.S. I90, 194 (I888) (holding that conflicting treaty stipulations and legislation are to be resolved in favor of the more recent); The Cherokee Tobacco, 78 U.S. (11 Wall.) 616, 621 (1870) (giving effect to $\S 107$ of the Internal Revenue Act of 1868 despite its conflict with a prior treaty with the Cherokee nation). On the other side of the ledger, however, there appears to have been only one example in which the Supreme Court has held a treaty to supersede an earlier statute. See Cook v. United States, 288 U.S. 102, 118-19 (I933). To make matters worse, the statute in Cook was a Prohibition-era liquor inspection statute that had been held in "low estate, was widely disregarded, and was about to be repealed." Henkin, supra note 5, at 210; see also Congressional Research Service, U.S. Library of Congress, The Constitution of the United States of America: Analysis and Interpretation 478-79 (Johnny H. Killian \& George A. Costello, eds. 1996). If anything, the operation of the last-in-time rule irdicates that it is asymmetrical-it apphes only when statutes violate treaty obligations-and thus that it supports the theory of the relationship between the treaty and legislative powers developed here.

94. See Richard H. Fallon, et al., Hart \& WechsIer's The Federal Courts and the Federal System 840-41 (4th ed. 1996) [hereinafter Hart \& Wechsler].

95. See, e.g., J.I. Case v. Borak, 377 U.S. 426, 430-32 (1964) (recoguizing a private cause of action under the Securities Exchange Act).

96. See, e.g., Central Bank of Denver v. First Interstate Bank of Denver, 511 U.S. 164, 191 (1994) (refusing to find private cause of action for aiding and abetting under $\$ 10(\mathrm{~b})$ of Securities Exchange Act of 1934); Hart \& Wechsler, supra note 94 , at 840 n.5 \& accompanying text (discussing the requirement of legislative intent). 
to be enforced by the executive branch, rather than by Congress or the courts. ${ }^{97}$

Judicial refusal to enforce statutory provisions may be even more pronounced when the case involves foreign affairs. In Tel-Oren v. Libyan Arab Republic, for example, the D.C. Circuit refused to hear a claim by the survivors of a terrorist attack on a civilian bus in Israel. ${ }^{98}$ In his concurrence, Judge Bork concluded that courts should not infer a cause of action under the Alien Tort Statute ${ }^{99}$ because, under the cause of action analysis, a court must examine the particular character of the issues presented for decision. ${ }^{100}$ Drawing upon both the act of state and the political question doctrines, Judge Bork found that the separation of powers required courts to defer to the political branches in foreign affairs, so as to avoid interference with the functions of the other branches and to prevent the judiciary from deciding issues that were not fit for judicial resolution.101 Taking "into account the concerns that are inherent in and peculiar to the field of international relations," Judge Bork concluded that the centralization of the conduct of foreign relations in the political branches constituted "'special factors counselling hesitation in the absence of affirmative action by Congress." 102 While Judge Bork's opinion is not offered here as representative of a broad practice by the courts, it exemplifies judicial reluctance to give self-executing effect to federal statutory provisions, especially in the foreign affairs area. ${ }^{103}$

97. See, e.g., Administrative Procedure Act, 5 U.S.C. $\$ 701$ (a) (2) (1994) (decision committed to agency discretion); Citizens to Preserve Overton Park v. Volpe, 401 U.S. 402 (1971) (discussing reviewability of Secretary of Transportation's authorization of highway funds).

98. 726 F.2d 774 (D.C. Cir. 1984).

99. 28 U.S.C. $\S 1350$ (1994).

100. See Tel-Oren, 726 F.2d at 801 (citing Davis v. Passman, 442 U.S. 228 (1979)).

101. See id. at 802-03.

102. Id. at 801 (quoting Bivens v. Six Unknown Named Agents of Federal Bureau of Narcotics, 403 U.S. 388, 396 (1971)).

103. Whether the Alien Tort Statute grants a private cause of action for torts that violate international law is a subject of judicial and academic controversy. See, e.g., Kadic v. Karadzic, 70 F.3d 232, 238 (2d Cir. 1995) (discussing jurisdictional requirements under the Alien Tort Act); Trajano v. Marcos, 978 F.2d 493, 499 (9th Cir. 1992) (discussing the requirement of the U.N. Convention Against Torture that states provide a private right of action for torture); Filartiga v. Pena-Irala, 630 F.2d 876, 887 (2d Cir. 1980) (recognizing Alien Tort Statute as a basis for jurisdiction). Most of the academic contretemps has centered around Professors Curtis Bradley and Jack Goldsmith's criticism of the incorporation of customary international law as federal common law. See Curtis A. Bradley \& Jack L. Goldsmith, The Current Illegitimacy of International Human Rights Litigation, 66 Fordham L. Rev. 319 (1997) (discussing alternative to the "Modern Position"); Curtis A. Bradley \& Jack L. Goldsmith, Customary International Law as Federal Common Law: A Critique of the Modern Position, 110 Harv. L. Rev. 815 (1997) (arguing that international law should not have the status of federal law without authorization by the federal pohtical branches); Curtis A. Bradley \& Jack L. Goldsmith, Federal Courts and the Incorporation of International Law, 111 Harv. L. Rev. 2260 (1998) (responding to Koh's critiques of their 1997 article); Ryan Goodman \& Derek P. Jinks, Filartiga's Firm Footing: International Human Rights and Federal Common Law, 66 Fordham L. Rev. 463 (1997) 
Judge Bork's Tel-Oren concurrence also explains judicial unwillingness to intervene in other foreign affairs questions, as expressed in the political question doctrine, the act of state doctrine, the reluctance to engage in dormant foreign affairs preemption, and the presumption against extraterritoriality. ${ }^{04}$

Vázquez's mistake in interpreting the Supremacy Clause to require automatic judicial enforcement of treaties is more dramatic when considered in light of the non-self-executing nature of constitutional provisions. Certain constitutional clauses cannot receive judicial implementation because the Constitution vests execution in the political branches. To take one example, much of Article 111 is non-self-executing, which leaves to Congress the decision whether to create the lower federal courts and to define their jurisdiction. ${ }^{105}$ In the Judiciary Act of 1789, the first Congress did not provide for federal jurisdiction over all of the cases and categories provided for in Article III. ${ }^{106}$ Indeed, for much of our nation's history, Congress did not provide for general federal question jurisdiction, and even today the diversity jurisdiction statute does not fully vest the lower courts with the full extent of jurisdiction possible under Article III, Section 2. Nor, for that matter, was Article III self-executing as to the creation of the federal court system. ${ }^{107}$ If something as vital to the constitutional system as the organization and jurisdiction of the judiciary is non-self-executing, despite the Supremacy Clause, it is difficult to understand why all treaties benefit from a contrary rule. Well-known justiciability doctrines, such as standing, mootuess, and ripeness, further

(putting forth a revisionist position); Harold $\mathrm{H}$. Koh, Is International Law Really State Law?, 111 Harv. L. Rev. 1824 (1998) (criticizing revisionist position); Gerald L. Neuman, Sense and Nonsense About Customary International Law: A Response to Professors Bradley and Goldsmith, 66 Fordham L. Rev. 371 (1997) (criticizing Bradley \& Goldsmith); Beth Stephens, The Law of Our Land: Customary International Law as Federal Law After Erie, 66 Fordham L. Rev. 393 (1997) (suggesting that Bradley \& Goldsmith improperly oversimplify the complexities of the Modern Position).

104. See Jack L. Goldsmith, The New Formalism in United States Foreign Relations Law, 70 U. Colo. L. Rev. 1395, 1424-29 (1999) (reviewing cases).

105. See Hart \& Wechsler, supra note 96 , at 28 . There is a strong debate, however, about whether certain classes of federal jurisdiction were considered mandatory and had to be vested by Congress in the federal courts. See, e.g., Amar, Neo-Federalist View, supra note 52, 260-62; Akhil Reed Amar, The Two-Tiered Structure of the Judiciary Act of 1789, 138 U. Pa. L. Rev. 1499 (1990); Robert N. Clinton, A Mandatory View of Federal Court Jurisdiction: Early Implementation of and Departures from the Constitutional Plan, 86 Colum. L. Rev. 1515, 1561-70 (1986).

106. See Hart \& Wechsler, supra note 96, at 32-33; Richard Casto, An Orthodox View of the Two-Tier Analysis of Congressional Control over Federal Jurisdiction, 7 Const. Commentary 89, 93 (1990).

107. Under the Madisonian compromise, Congress was given the discretion to establish lower federal courts or to rely on the state courts to enforce federal law. See Hart \& Wechsler, supra note 94 , at $7-9$. 
preclude courts from adjudicating all cases that raise questions of federal law. 108

Of particular importance for our discussion is the political question doctrine, which is relevant not just as another example of the judicial under-enforcement of constitutional norms, but because it suggests that foreign affairs cases may receive less judicial attention than others. Despite withering criticism by international law scholars, the courts seem intent to enforce the doctrine where foreign affairs are concerned. ${ }^{109}$ Federal courts famously liave refused to hear cases challenging the President's use of military force without a declaration of war, both during the 1980 s and $1990 \mathrm{~s}^{110}$ and during the Vietnam War. ${ }^{111}$ Treaty cases also have triggered the political question doctrine. In Goldwater v. Carter, a four-Justice plurality agreed that the question whether the President could terminate treaties without the consent of the Senate presented a non-justiciable political question. ${ }^{112}$ And as Justice Brennan wrote for the Court in Baker v. Carr, "[n] ot only does resolution of [foreign affairs] issues frequently turn on standards that defy judicial application, or involve the exercise of a discretion demonstrably committed to the executive or legislature; but many such questions uniquely demand singlevoiced statement of the Government's views."113 In earlier cases, according to the Court, these reasons had led it to apply the political question doctrine to avoid reviewing foreign affairs decisions of the political branches. ${ }^{114}$ A similar concern about a lack of judicial ability has led

108. See Henry P. Monaghan, Constitutional Adjudication: The Who and When, 82 Yale L.J. 1363, 1379-86 (1973).

109. See generally John Hart Ely, War and Responsibility: Constitutional Lessons of Vietnam and its Aftermath 55-56 (1993); Thomas M. Franck, Pohitical Questions/Judicial Answers: Does the Rule of Law Apply to Foreign Affairs? 3-9 (1992); Michael J. Glennon, Constitutional Diplomacy, xix-xxi (1990); Harold H. Koh, The National Security Constitution: Sharing Power After the Iran-Contra Affair (1990); Michael Tigar, Judicial Power, the "Political Question Doctrine," and Foreign Relations, 17 U.C.L.A. L. Rev. 1135, $1135-36$ (1970).

110. See, e.g., Sanchez-Espinoza v. Reagan, 770 F.2d 202, 210 (D.C. Cir. 1985) (dismissing a war powers claim as not ripe for judicial review); Crockett v. Reagan, 720 F.2d 1355,1356 (D.C. Cir. 1983) (holding that the war powers issue presented a nonjusticiable political question); Dellums v. Bush, 752 F. Supp. 1141, 1146 (D.D.C. 1990) (holding that "the judicial Branch should not decide issues affecting the allocation of power between the President and Congress until the pohitical branches reach a constitutional impasse"); Ange v. Bush, 752 F. Supp. 509, 512-15 (D.D.C. 1990); Lowry v. Reagan, 676 F. Supp. 333, 340 (D.D.C. 1987) (holding that the "judicial branch ... is neither equipped or einpowered to intrude into the realm of foreign affairs).

111. See, e.g., DaCosta v. Laird, 405 U.S. 979 , 979 (1972); Massachusetts v. Laird, 400 U.S. 886 (1970) (finding challenge to Vietnam War a nonjusticiable pohitical question); Mora v. McNamara, 389 U.S. 934, 934 (1967); Holtzman v. Schlesinger, 484 F.2d 1307, 1310 (2d Cir. 1973).

112. 444 U.S. 996, 1002 (1979) (plurality opimion of Rehnquist, J.).

113. 369 U.S. at 211.

114. See, e.g., Chicago \& S. Air Lines v. Waterman S.S. Corp., 333 U.S. 103, 111 (1948); Oetjen v. Central Leather Co., 246 U.S. 297, 302 (1918). 
lower courts since Baker to dismiss challenges by individuals against government actions involving foreign affairs. ${ }^{115}$

The Baker Court's discussion of the political question doctrine indicates that the courts should not get involved because of their lack of capacity to handle difficult foreign affairs cases. Another factor, however, also animates the doctrine's operation in this field: the structural superiority of the other branches to handle foreign affairs. In this respect, Justice Brennan's views echoed Justice Sutherland's opinion for the Court in United States $v$. Curtiss-Wright, in which the Court observed that the force of the non-delegation doctrine ought to be significantly relaxed in foreign affairs. "Not only is the federal power over external affairs in origin and essential character different from that over internal affairs," Justice Sutherland wrote, "but participation in the exercise of power is significantly limited." Because foreign affairs took place "[i]n this vast external realm, with its important, complicated, delicate and manifold problems," he concluded, the courts ought to defer to the President.116 In raising political question concerns in Goldwater $v$. Carter, Justice Rehnquist also relied upon Sutherland's language in Curtiss-Wright to urge deference to the political branches. To be sure, academics have rightly criticized Curtiss-Wright on a number of grounds. ${ }^{117}$ Nonetheless, these criticisms do not address Curtiss-Wright's theme that the political branches, acting together, are structurally superior to the judiciary in managing the nation's foreign affairs, and that therefore their decisions in this area ought to receive some amount of judicial deference.

Non-self-execution better accords with the constitutional allocation of the foreign affairs power than Vázquez's broad rule requiring that courts automatically enforce all treaties. By refusing to enforce treaties without implementing legislation, the courts can avoid the difficult policy questions inherent in determining how best to execute the nation's international obligations. These are problems for which the federal courts are ill-suited from a functional point of view, and for which they ought to defer, for structural reasons, to the other branches. Both the President and Congress possess institutional capabilities and resources that render them superior to the courts in shaping how the nation should live up to its treaty commitments. Because the Constitution does not compel a rule of self-execution for even all constitutional or statutory provisions, the courts have the flexibility to adopt a rule that better makes sense of the Constitution's textual division of the treaty and legislative powers and honors the political branches' leading role in foreign affairs.

115. See, e.g., Crockett v. Reagan, 720 F.2d 1355 (D.C. Cir. 1983); Lowry v. Reagan, 676 F. Supp. 333 (D.D.C. 1987); Goldsmith, supra note 104, at 1414-18.

116. 299 U.S. at 319.

117. See, e.g., Charles A. Lofgren, United States v. Curtiss-Wright Export Corporation: An Historical Reassessnient, 83 Yale L.J. 1 (1973); David M. Levitan, The Foreign Relations Power: An Analysis of Mr. Justice Sutherland's Theory, 55 Yale L.J. 467 (1946). 


\section{An Alternative Approach to the Supremacy Clause}

Finally, Vázquez errs because he misconstrues the Supremacy Clause as a separation of powers provision, rather than as a federalism provision, and because he rushes to equate "Law of the Land" with automatic judicial enforcement. Yet the Clause's text does not clearly call for immediate judicial execution of all treaty provisions, and it instead allows the political branches to take the lead. Vázquez believes that the text of the Supremacy Clause is as clear as the requirement that the President be at least 35 years old. He and other internationalists, however, fail to explain why the Clause's words, "Law of the Land," must mean automatic judicial enforcement. To be sure, making a species of federal enactment a "law of the land" expresses its superiority over inconsistent state law. ${ }^{118}$ But the "law of the land" phrase does not address how that supremacy is to be achieved. A constitutional, statutory, or treaty provision can achieve "law of the land" status through presidential or congressional, rather than judicial, action. One might even read the "Law of the Land" phrase as an affirmative duty of the federal government, as a whole, to give effect to constitutional, statutory, or treaty obligations. This would give treaties domestic effect outside of the courts, although the executive and legislative branches would remain free to break a treaty.119

Contrary to Vázquez's arguments, the Supremacy Clause does not specify what branch or branches within the federal government bear the primary responsibility for treaty implementation. Mere use of the phrase "Law of the Land," by itself, does not establish a priority of obligation that requires the judiciary to act first, in the absence of guidance from the political branches. In fact, if Vázquez's reading were correct, then the third part of the Clause would have proven unnecessary. If Vázquez were right that making a type of federal enactment the "Law of the Land" obviously vests it with automatic judicial enforcement, then requiring state judges to give effect to the Constitution and laws, "any Thing in the Constitution or Laws of any State to the contrary notwithstanding" would have been surplusage. 120 If "Law of the Land" obviously meant "immediate judicial enforcement," then the Supremacy Clause need not have mentioned state judges at all.

The meaning of "Law of the Land" is not the only textual problem with Vázquez's reading of the Supremacy Clause. What should be clear, upon a cursory reading of the Clause, is that it fails to address the relationship of the treaty power and the legislative power. While the Clause does declare the supremacy of federal law over state law, it does not alter

118. See McCulloch v. Maryland, 17 U.S. (4 Wheat) 316, 435-36 (1819).

119. Professor Vázquez takes me to task for equating whether a treaty is a law of the land, and therefore domestic law, with whether a treaty is enforceable in court. That was not my intent. I readily agree that a constitutional or statutory provision can be law without judicial enforcement; the obligation of enforcing the law just shifts to another actor, but that does not make the provision any less binding.

120. See Vázquez, Laughing at Treaties, supra note 3, at 2157-58. 
the existing relationships between different types of federal law and their methods of enforcement. As Albert Gallatin put it during the Jay Treaty debates, the Clause

does not compare a treaty with the law of the Umited States, or either of them with the Constitution: it only compares all the acts of the Federal government with the acts of the individual States, and declares that either of the first, whether under the name of Constitution, law, or Treaty, shall be paramount to and supersede the Constitution and laws of the individual States. ${ }^{121}$

The Supremacy Clause did not address the division of the legislative and executive treaty powers because that allocation had already been made by the Constitution. As Madison put it, "[T]he term supreme, as applied to Treaties, evidently meant a supremacy over the State constitutions and laws, and not over the Constitution \& laws of the U. States . . .."122

The Supremacy Clause's federalism purpose becomes even clearer when one examines the governmental actors it regulates. The Clause requires only state judges to give effect to federal laws, even when they come into conflict with state constitutional or legislative provisions. It does not discuss the relative roles of the President, Senate, and House. It does not even address the duties of federal judges in giving supremacy effect to treaties, not to mention the obligations of state executives and legislatures. Said Madison during the Jay Treaty debates: "[T] he Judicial authority \& the existing laws, alone of the States, fell within the supremacy expressly enjoined. The injunction was not extended to the Legislative authority of the States or to laws requisite to be passed by the States . . .."123 If, as Madison believed, the Supremacy Clause does not even address whether and how state executives and legislatures must give effect to treaties, it is hard to read it as establishing a rule concerning the relative roles of the political branches and the federal judiciary on treaty implementation. If the Supremacy Clause were to shoulder the burden that Vázquez places upon it-overturning the traditional separation of the treaty and legislative powers-one would expect it to say so.

The Clause's placement in Article VI further underscores its federalism purpose. The provisions that allocate the powers of the three branches are found in the first three articles of the Constitution. By the time one reaches Article IV, the Constitution no longer addresses the powers of the branches vis-à-vis each other, but instead turns to powers that had to be vested in the nation as a whole. Article VI addresses whether the pre-revolutionary debts are valid against the new government, the nature of the oath to the Constitution that is to be taken by federal and state officials, and the supremacy of Federal law. None of these provisions seek to play any role in the separation of powers, nor do any of them meddle with the powers held by the different branches of

121. 5 Annals of Congress 468 (1796) (speech of Albert Gallatin).

122. Madison Papers, supra note 17, at 256.

123. Id. 
government. If the Constitution had sought to re-allocate part of Congress's legislative power to the President and Senate acting by treaty, then Article VI would have been an odd place, indeed, to have done so. It would have been as if the Constitution, in Article VII, had included a clause allowing Congress to shield all federal officers from presidential removal or direction. ${ }^{124}$

Vázquez responds that interpreting the Supremacy Clause to not compel self-execution reads the word "treaties" out of the clause. ${ }^{125}$ If all treaties required legislative implementation, there would have been no need for "treaties" in Article VI because every treaty would already have been implemented by a statute. This is perhaps the best textualist claim that internationalists can make. It would only apply, however, if I were claiming that all treaties were non-self-executing, regardless of whether they fell within Congress's Article I powers or not. However, treaties that touch on areas that are regulated by the states do not, by their very definition, infringe on Congress's legislative powers. While non-self-execution allows us to read the treaty power in harmony with Article I's vesting of the legislative power in Congress, it is unnecessary when the treaty power involves matters within the jurisdiction of the states.

Acknowledging that certain treaties may extend beyond Congress's powers allows us to give meaning to the word "treaties" in the Supremacy Clause while preserving Article I's vesting of the legislative power. If a treaty regulates a matter within the jurisdiction of the states, then the word "treaty" in the Supremacy Clause provides Congress with the authority to pass a statute preempting state law to give effect to the treaty. Without the word "treaty" in the Clause, a federal statute that sought to implement such treaty obligations would run afoul of the Tenth Amendment or other federalism protections. Giving the word "treaty" this role is more consonant with the Clause's overall objective of preventing states from resisting the enforcement of federal law, rather than giving it the completely different separation of power purpose of vesting treaties with aspects of the legislative power. This reading has the virtue of explaining how Ware v. Hylton ${ }^{126}$ and the Jay Treaty debates could occur both contemporaneously and harmoniously. Ware did not contradict the non-selfexecution rule urged by "Globalism" because the provisions of the peace treaty at issue regulated matters that, at the time, would not have fallen within Congress's Article I powers. ${ }^{127}$ The Jay Treaty, on the other hand, did fall within those powers, and so sparked a sharp controversy among

124. Professor Vázquez spends some time knocking down the straw man argument that the Supremacy Clause's use of the phrase "shall be made" cannot serve as the justification for non-self-execution. I wholly agree with him.

125. See Vázquez, Laughing at Treaties, supra note 3, at 2171.

126. 3 U.S. (3 Dall.) 199 (1796).

127. The peace treaty also may not have required implementing legislation because it had heen made before the ratification of the Constitution, and so the Constitution may have implemented it directly. 
the branches, which was resolved in favor of a theory of non-self-execution. This reading also provides for the result in Missouri $v$. Holland. ${ }^{128}$ Missouri's reasoning has troubled commentators because it fails to explain exactly where, in the Constitution, the federal government receives the power to enforce treaties that go beyond Congress's Article I powers. ${ }^{129}$ Reading the word "treaty" in the Supremacy Clause in the manner suggested here provides Missouri with the textual hook that it has lacked.

Vázquez also suggests that non-self-execution robs treaties of any significance. If a treaty cannot take effect without an implementing statute, what is the point of having a treaty in the first place? This argument has a pedigree that goes back to Alexander Hamilton, who argued that Congress had a constitutional obligation to appropriate money and pass legislation to implement the Jay Treaty. As Hamilton wrote, "there is scarcely any species of treaty which would not clash, in some particular, with the principle" that treaties cannot exercise Article I power. ${ }^{130}$ If such were the case, he continued, then "the power to make treaties granted in such comprehensive and indefinite terms and guarded with so much precaution would become essentially nugatory." 131 The problem with this argument, however, is that it considers treaties only in terms of their domestic effects. Internationalists, ironically, ignore the important role of treaties as an instrument of international relations. Even if a treaty were not implemented domestically, it is, once made, an instrument governed by international law that imposes obligations on the United States. Treaties still remain the primary vehicle by which the United States makes longterm commitments of a political or military nature with other nations. If anything has made treaties less meaningful, it is not non-self-execution, but the growing use of congressional-executive agreements. Although the constitutionality of congressional-executive agreements has bedeviled recent commentators, ${ }^{132}$ the theory of legislative power presented here provides the straightforward answer that such agreements can be seen as implementing legislation, without the form of the treaty itself.

Vázquez's theory of self-execution suffers just as much at the hands of practice as at the hands of text and structure. He cannot deny that

128. 252 U.S. $416(1720)$.

129. See, e.g., Bradley, supra note 15, at 424-25 (discussing "concern after [Missouri] that the treaty power might not be subject to any constitutional restraints, including the individual rights provisions of the Bill of Rights").

130. Alexander Hamilton, The Defense No. 37, N.Y. Herald, Jan. 6, 1796, reprinted in 20 Hamilton Papers, supra note 48, at 13, 18.

131. Id.

132. See, e.g., Bruce Ackerman \& David Golove, 1s NAFTA Constitutional?, 108 Harv. L. Rev. 799 (1995) (defending NAFTA's constitutionality based on a theory of higher lawmaking, and arguing that the weighty political developinents of the New Deal era effected constitutional change); Laurence $\mathrm{H}$. Tribe, Taking Text and Structure Seriously: Reflections on Free-Form Method in Constitutional Interpretation, 108 Harv. L. Rev. 1221, 1249-78 (1995) (challenging Ackerman's approach to constitutional interpretation and urging a return to text and structure). 
there are many instances in which courts refuse to enforce treaties in properly-brought cases. His efforts to classify non-self-executing treaties notwithstanding, the fact remains that non-self-execution has been a part of American law since as early as Chief Justice Marshall's decision in Foster v. Neilson. ${ }^{133}$ Furthermore, he cannot deny that the political branches have long engaged in a practice of attaching reservations, understandings, and declarations to treaties that have rendered parts or all of them non-self-executing. ${ }^{134}$ These reservations often are not even part of the text of the treaty itself, but are instead sometimes expressed in the Senate's resolution approving the treaty, and sometimes only in the legislative history. If one values judicial precedent and longstanding practice by the political branches, then the presence of a long tradition of non-selfexecution is a fatal blow to Vázquez's case. Simply reading "Laws of the Land" to mean automatic judicial enforcement provides for no exceptions. ${ }^{135}$

Despite his best effort to avoid a choice between text and practice, Vazquez still offers no convincing way to reconcile the two. Creating a presumption that treaties are to be considered self-executing does not really alleviate the conflict. First, the presumption does not actually protect any other constitutional values, but instead serves only as begrudging

133. 27 U.S. (2 Pet.) 253 (1829). Professor Vázquez's discussion of Foster is puzzling. He goes to great lengths to prove that Chief Justice Marshall recognized in Foster that the Supremacy Clause renders all treaties self-executing. Yet, it is quite clear that in Foster itself the Court found that the treaty at issue was not self-executing, and that it reached this conclusion because Marshall believed that the choice of treaty execution should be left primarily to the pohtical branches. To say simply that Marshall found for self-execution, but then when he addressed the treaty at hand "he seemed to lose sight of this presumption," Vázquez, Laughing at Treaties, supra note 3, at 2194, fails to explain why the Court acted as it did in Foster. As I admit in "Globalism," the Court in United States v. Percheman, 32 U.S. (7 Pet) 51 (1833), reversed Foster's interpretation of the treaty at hand. A remarkable case worth detailed historical study, Percheman did not reverse the doctrine expressed in Foster, although it rejected Foster's application of that doctrine.

134. See, e.g., Lori Fisler Damrosch, The Role of the United States Senate Concerning "Self-Executing" and "Non-Self-Executing" Treaties, in Parliamentary Participation in the Making and Operation of Treaties: A Comparative Study 205, 207-13 (Stefan A. Riesenfeld \& Frederick M. Abbott eds., I994) (describing practice of President and Senate); Stefan A. Riesenfeld \& Frederick M. Abbott, The Scope of U.S. Senate Control over the Conclusion and Operation of Treaties, in Parliamentary Participation in the Making and Operation of Treaties: A Comparative Study, supra, at 261 (criticizing Senate reservations rendering treaties non-self-executing).

135. See Vázquez, Laughing at Treaties, supra note 3, at 2176-83; Carlos Manuel Vázquez, The Four Doctrines of Self-Executing Treaties, 89 Am. J. Int'l L. 695, 696-97 (1995). While Vázquez has twice undertaken the valiant effort of categorizing the different types of non-self-executing treaties, description does not provide a justification for these significant deviations. Unless internationalists have produced a new theory of constitutional interpretation that reconciles text with conflicting practice, then they either must abjure much of the history of American foreign relations, or they must accept practices that directly reject their theories. If including treaties in the Supremacy Clause displayed a clear intention to render all treaties automatically enforceable in court, then all three branches have been seriously derelict in their constitutional duties for some time. 
acknowledgement of a practice that fails to fit within Vazquez's unsparing views. Conceding that an exception exists to a rule does not provide an independent justification for it. Second, the presumption is of little value in a time when, as many commentators have observed, the political branches regularly declare treaties to be non-self-executing. ${ }^{136}$ If anything, practice indicates that the three branches have adopted the opposite presumption. Third, the presumption does not explain cases in which courts have found treaties non-self-executing even in the absence of a direct order by the political branches to do so.

This Rejoinder began by building upon the historical evidence presented in "Globalism" to show that the text and structure of the Constitution, properly understood, justifies a rule of non-self-execution. It will end, in response to Vázquez's claims that "Globalism" is ambiguous in its policy recommendations, by suggesting doctrinal ways to promote these principles. If a treaty clearly states on its face that it is to be automatically enforced by the courts, then the judiciary has two choices. If the treaty regulates areas within Congress's Article I powers, then the courts should refuse to execute it without congressional implementation. However, if the treaty addresses a matter outside of Congress's powers, there is a different result. A treaty that regulates matters within the exclusive powers of the states would provoke no conflict with Congress's plenary authority over federal legislation. Therefore, the judiciary could enforce the provisions of the treaty under the Supremacy Clause against inconsistent state law. Or, in the alternative, it could preempt inconsistent state law as a matter of federal common law, thereby leaving the field open for Congress to choose how to implement the treaty. ${ }^{137}$

This hard rule, however, cannot claim to fully fit current practice. I am willing to accept that there are cases in which courts have given some treaties self-executing effect. ${ }^{138}$ Neither "Globalism" nor this Rejoinder

136. See Natalie Hevener Kaufman, Human Rights Treaties and the Senate: A History of Opposition 172 (1990); Damrosch, supra note 134, at 205-21; Louis Henkin, U.S. Ratification of Human Rights Conventions: The Ghost of Senator Bricker, 89 Am. J. Int'l L. 341, 346-48 (1995); Riesenfeld \& Abbott, supra note 134, at 261-327.

137. Cf. Bradford R. Clark, Federal Coinmon Law: A Structural Reinterpretation, 144 U. Pa. L. Rev. 1245, 1271-99 (1996) (arguing that judicial federalism concerns do not apply to certain federal common law rules, including the Act of State Doctrine, allowing federal law in such imstances to preempt state law).

138. Internationalists cannot show, however, a widespread practice that courts find all treaties self-executing. While examining in detail all of the Supreme Court cases cited by internationalists is beyond the scope of this Rejoimder, a quick review shows that almost all of them - with a few exceptions-involve treaties that displace state regulations. The great majority of the recent cases involve the Warsaw Convention, which limits the damages that plaintiffs may receive under state tort law for airplane accidents. See, e.g., El Al Israel Airlines, Ltd. v. Tseng, 525 U.S. 155 (1999) (claim for assault and false imprisonment stemuning from "intrusive security search" preempted by the Convention); Eastern Airlines, Inc. v. Floyd, 499 U.S. 530 (1991) (no liability under the Convention for mental distress due to nearly crashing into the Atlantic Ocean); Clan v. Korean Air Lines, Ltd., 490 U.S. 122 (1989) (the Convention's damages limitation applies even if no notice is 
has relied upon practice, because the text, structure and original understanding of the Constitution already provide the best reading of the place of treaties in our public lawmaking system. In a second-best world, however, in which courts must take account of previous decisions, judges can still remain true to the constitutional text and structure by adopting a fallback rule-a clear statement requirement that treaties are non-selfexecuting unless the treatymakers openly declare otherwise. While a clear statement rule does not perfectly account for previous judicial precedent, there is strong evidence that lower courts have already adopted such an approach. ${ }^{139}$ This clear statement rule is also consistent with the

printed on passenger tickets); Air France v. Saks, 470 U.S. 392 (1985) (limiting "accidents" under the Convention to harms that result from abnormal accurences during air travel); Trans World Airlines, Inc. v. Franklin Mint Corp., 466 U.S. 243 (1984) (upholding currency value measurement based on gold standard for international settlements under the Conventions). While the substantive terms of the Warsaw Convention perhaps could be passed by Congress, on the same basis as that for national tort reform, it may be that the Warsaw Convention presents a unique case because of its closeness to the line where state prerogatives over tort law begin to apply. The other cases relied upon by internationalists do not involve areas where treaties threatened to infringe on Congress's Article I, Section 8 powers. For example, the most prominent case cited by internationalists involved a treaty with Japan that guaranteed its citizens equal treatment by state law in the United States; no congressional powers were implicated. See Asakura v. City of Seattle, 265 U.S. 332 (1924). A few other cases raise very complex issues that do not even appear to support a theory of treaty self-execution. See, e.g., United States v. Stuart, 489 U.S. 353 (1989) (IRS summons not prohibited by either treaty or statute); Holden v. Joy, 84 U.S. (17 Wall.) 211 (1872) (President's authority to negotiate agreements with Indians pursuant to congressional authorization).

139. See, e.g., Goldstar (Panama) S.A. v. United States, 967 F.2d 965, 968 (4th Cir. 1992) (finding that the Hague Convention is non-self-executing because "courts will only find a treaty to be self-executing if the document, as a whole evidences an intent to provide a private right of action . . . "); More v. Intelcom Support Servs., Inc., 960 F.2d 466, 469 (5th Cir. 1992) (following Frolova, held treaty between United States and Plilippimes to be non-self-executing); Frolova v. Umion of Soviet Socialist Republics, 761 F.2d 370, 373 (7th Cir. 1985) ("if not implemented by appropriate legislation [treaties] do not provide the basis for a private lawsuit unless they are intended to be self-executing"); Canadian Transp. Co. v. United States, 663 F.2d 1081, 1092 (D.C. Cir. 1980) (Treaty of Commerce and Navigation of 1815 between the United States and Great Britain held to be non-selfexecuting); Mannington Mills, Inc. v. Congoleum Corp., 595 F.2d 1287, 1298 (3d Cir. 1979) (Paris Convention of 1883 and the Pan-American Convention of 1910 held to be non-self-executing); United States v. Postal, 589 F.2d 862, 876-77 (5th Cir. 1979) (holding Art. 6 of the Convention on the High Seas to be non-self-executing); Diggs v. Riclardson, 555 F.2d 848, 851 (D.C. Cir. 1976) (holding United Nations Security Council Resolution to be non-self-executing); Dreyfus v. Von Finck, 534 F.2d 24, 30 (2d Cir. 1976) (holding Hague Convention, Kellogg-Briand Pact, Treaty of Versailles, and Four Power Occupation Agreement all to be non-self-executing); People of Saipan v. United States Dep't of Interior, 502 F.2d 90, 97 (9th Cir. 1974) (applying intent-based analysis to find Trusteeship agreement over Saipan to be judicially enforceable). See also Curtis A. Bradley, Breard, Our Dualist Constitution, and the Internationalist Conception, 51 Stan. L. Rev. 529, 541 \& n.62 (1999) ("many courts in recent years have held that they will not find a treaty to be self-executing unless there is affirmative evidence of such intent"); Goldsmith, supra note 104 , at 1429 \& $n .126$ (citing cases demonstrating that "[i]n recent years courts [have] presume[d] that a treaty is non-self-executing"). 
political branches' practice of attaching RUDs to recent human rights treaties. The clear statement rule would approximate the conduct of courts that have adopted a private right of action analysis, which generally refuses to enforce a treaty unless its text clearly indicates the treatymakers' intentions to grant plaintiffs a right to sue in court. ${ }^{140}$

A super-strong clear statement rule, as Professors Eskridge and Frickey have called it, ${ }^{141}$ allows the Court both to avoid difficult constitutional questions and to protect the constitutional structure, without having to block actions by the political branches. Here, the constitutional questions are clear: first, whether the treatymakers can exercise legislative powers vested in Congress; and second, whether the national government as a whole can use its treaty power to regulate matters within the jurisdiction of the states. A clear statement rule also advances important values in the constitutional management of the nation's foreign affairs. The Constitution undeniably vests the conduct of international relations in the President and Congress. In the presence of textual silence, a clear statement rule gives the political branches the flexibility to determine precisely how to calibrate foreign policies that involve treaties. In the absence of specific instructions, courts may be unable to judge whether the treatymakers actually intend to take the constitutionally dangerous step of making a treaty self-executing. By adopting a clear statement rule, the courts can force the political branches to provide more information concerning treaty implementation. Judicial deference in this situation prevents courts from engaging in unauthorized foreign policy judgments. It can be argued that a non-self-execution rule, therefore, is consistent with other developments in foreign relations law that have sought to limit judicial discretion in areas such as the act of state doctrine, the political question doctrine, and dormant preemption.

Non-self-execution is not limited solely to the judiciary. As a matter of doctrine, the problems created by treaties in the public lawmaking process counsel the treatymakers to place RUDs upon treaties that render them non-self-executing. These RUDs are most necessary when treaties appear, on their face, to require judicial enforcement in the absence of implementing legislation, as in the case with human rights treaties. The

140. Although Professor Vázquez repeatedly argues that a private right of action analysis still does not prevent individuals from raising treaty-based claims as part of a suit based on a federal law such as 42 U.S.C. $\$ 1983$ or the Administrative Procedure Act, the text of those statutes fails to support him. 42 U.S.C. $\$ 1983$, for example, states that a plaintiff may sue if a state official has subjected him or her to "the deprivation of any rights, privileges, or immunities secured by the Constitution and laws . . ." 42 U.S.C. $\$ 1983$ (1994). The language quite specifically leaves out a claim based upon a treaty right. Similarly, the APA allows courts to set aside agency action that is "not in accordance with law," that is "contrary to constitutional right, power, privilege, or immunity," or that is "in excess of statutory jurisdiction, authority, or limitations, or short of statutory right." 5 U.S.C. $\$ 706$ (2) (A), (B), (C) (1994). Again, the very text of the APA specifically refuses to include treaties as the basis for a claim heard in federal court.

141. See Eskridge \& Frickey, supra note 9, at 597. 
purposes behind the clear statement rule explain what Vázquez and others cannot: how RUDs can countermand their interpretation of the Supremacy Clause, even though RUDs often are not expressed in the treaty text. While internationalists are reduced to admitting that even a presidential statement can override a validly enacted law, this Rejoinder understands RUDs as communicating the desire of the political branches that the courts follow the non-self-execution presumption. Indeed, the increasing use of RUDs over time may have signaled the political branches' agreement that non-self-execution should become the general rule applied to all treaties.

A clear statement rule, finally, plays two broader roles in the public lawmaking system. First, such an approach requires the political branches to deliberate before they decide to take an action that undermines the constitutional text and structure. While it admits that some practice has strayed from the best reading of the Constitution, it seeks to encourage the political branches to take the Constitution seriously when it acts in the arena of international politics. Second, a clear statement rule helps contain the potential for unlimited lawmaking at a time when the line between domestic and international affairs is disappearing. Globalization, plus the interaction of several internationalist positions about the unbounded subject-matter of treaties, their freedom from the restraints of the separation of powers and federalism, and their alleged interchangeability with statutes, threatens to give the treatymakers a legislative power with few limits. A clear statement rule ensures that treaties, like the Constitution itself and all other species of federal law, are true to the notion that the national government is one of limited, enumerated powers.

\section{ConCLUSION}

I originally undertook the inquiry that produced "Globalism" and the Constitution to address a question that I thought would become one of the most difficult and important questions for the structural Constitution in the near future: How will the domestic legal system adapt to the internationalization of political, economic, and social life? I also began the study because the issue of self-executing treaties contains within it important issues concerning the relationship of the foreign relations power with the legislative power, and the role of the courts in mediating that relationship. Non-self-execution is an area where practice has diverged sharply from the scholarly consensus, and where the three branches of government have been exposed to some startling criticism from academics. All this presents a fascinating tension between political and judicial practice on the one hand, and academic theories on the other.

In writing such extensive and thoughtfully-argued comments on "Globalism," Professors Flaherty and Vázquez have fulfilled my broadest goal in writing "Globalism." It was my hope to spur a more balanced, principled dialogue over certain conclusions of law that are widely ac- 
cepted by most foreign relations law scholars, but which have not undergone careful scrutiny or debate. "Globalism" sought to promote this dialogue by applying standards and methods that prevail in other areas of constitutional law to an important foreigu relations question, that of selfexecuting treaties. In taking up "Globalism's" challenge, Professors Flaherty and Vázquez have published defenses for a broad doctrine of selfexecuting treaties that go beyond the sometimes weak standards in foreign relations law scholarship. Nonetheless, they fail to hit the mark, for the historical, textual and structural reasons reviewed here.

Yet, at a different level, the Responses by Professor Flalierty and Vázquez are bittersweet, because in tone they are of a piece with other reactions to new directions in thought in foreigu relations law. The foreign relations law community seems to have a tendency to accept certain conclusions of law with the slightest of scrutiny. Sometimes utter unanimity surrounds certain conclusions, such as whether customary international law should be incorporated as federal common law, or whether the President should have unilateral authority to engage in military hostilities abroad, or whether treaties should be self-executing, with a minimum of debate. When those propositions are later challenged by sincere intellectual criticism, the international law community often responds by claiming that these conclusions are motivated either by "isolationism" or by an almost senseless desire to roil what are peaceful waters, rather than by engaging the arguments on the merits. ${ }^{142}$ Flalierty and Vázquez steer clear of such reactions generally, although one detects a similar tone of frustration in having to address criticism of what they properly conceive to be one of the central positions of the internationalist consensus.

Revisionism, particularly the constant re-evaluation of the correctness of scholarly consensus, can only be healthy for the study of law. To compare the desire to settle questions of foreign relations law to the need to have certainty in legal rules only indicates a reluctance to open up certain conclusions to intellectual debate. Perhaps the uncertainty whether international law is really law originally led internationalist scholars to circle the wagons when it came to important questions central to the relevance of international law to domestic affairs. Such an attitude, unfortunately, probably produced the many years of stunted growth in foreign relations law, even when exciting changes in constitutional law, unprecedented development in international affairs, and advancements in the related disciplines of political science and economics, should have produced the opposite result. If foreign relations and international law scholarship is to play a meaningful role in managing the globalization of American life, it will have to do better in the future. It is my hope that "Globalism" and this Rejoinder help in the ongoing effort to reinvigorate the discourse in these most important fields of scholarship.

142. In particular, I have in mind the running debate between Professors Curtis Bradley and Jack Goldsmith and their critics concerning the incorporation of customary international law as federal common law. 